\title{
ARBITRAGEM NA INDÚSTRIA DO PETRÓLEO NO DIREITO BRASILEIRO
}

\author{
Carmen Tiburcio* e SuZana Medeiros**
}

I - Introdução; II - Vantagens da Utilização da Arbitragem nos Contratos de Concessão para Exploração e Produção de Petróleo e Gás; III - Arbitragem na Lei do Petróleo; a) Art. 20; b) Art. 27, parágrafo único; c) Art. 43, inciso $X ; I V-$ Arbitragem nos Contratos de Concessão das Rodadas de Licitação da ANP; a) rodada zero; b) primeira rodada; c) segunda rodada; d) terceira rodada; e) quarta e quinta rodadas; $f$ ) sexta rodada; $g$ ) sétima rodada; $V$ - Conclusão.

\section{I - Introdução}

A arbitragem é atualmente o meio de solução de controvérsias mais utilizado no âmbito do comércio internacional. Na indústria do petróleo, a via arbitral também vem adquirindo posição de destaque, não só nos contratos de concessão (ou similares) para exploração e produção de petróleo e gás, mas também nos contratos privados, como o Joint Operating Agreement (JOA). A análise da arbitragem nos contratos privados da indústria estará, todavia, fora do escopo deste trabalho.

O presente estudo buscará, primeiramente, apresentar as vantagens de se optar pela arbitragem como via de solução de controvérsias dos contratos de concessão para exploração e produção de petróleo e gás. Além disso, serão analisados e interpretados os artigos da Lei do Petróleo brasileira (Lei $n^{\circ}$ 9.478/97) que se referem - ainda que aparentemente - à arbitragem, levantando-se os principais pontos controvertidos desses dispositivos. Por fim, far-se-á uma análise minuciosa das cláusulas de conciliação, arbitragem e eleição de foro dos contratos de concessão

* Professora Adjunta de Direito Internacional Privado e de Direito Processual Internacional da Faculdade de Direito da UERJ. Mestre e Doutora em Direito Internacional pela Faculdade de Direito da Universidade de Virginia, EUA.

** Mestre em Direito Internacional pela Faculdade de Direito da UERJ e pela New York University. Advogada em Washington D.C

R. Dir. Adm.,

Rio de Janeiro, 241: 53-91,

Jul./Set. 2005 
para exploração e produção de petróleo e gás das rodadas de licitação realizadas pela Agência Nacional do Petróleo até o momento. Assim, o presente estudo estará restrito à análise do tema no direito brasileiro, com breves referências pontuais ao direito comparado.

\section{II - Vantagens da Utilização da Arbitragem nos Contratos de Concessão para Exploração e Produção de Petróleo e Gás}

A adoção da cláusula compromissória no âmbito dos contratos de concessão (e similares) para exploração de petróleo e gás ${ }^{3}$ representa um grande atrativo aos investidores que atuam na indústria do petróleo.

Primeiramente, a possibilidade de ter as disputas decorrentes desses contratos solucionadas por um meio neutro e imparcial, fora do âmbito do Poder Judiciário do país hospedeiro (na maioria dos países o contrato de concessão é celebrado pelo próprio Estado ou por uma agência ou empresa estatal que detém a propriedade ou os direitos de exploração do petróleo e do gás), garante uma enorme segurança para o investidor estrangeiro. Além disso, no juízo arbitral mais facilmente afasta-se a questão da imunidade de jurisdição do Estado hospedeiro, pois a doutrina majoritária entende que esse princípio não se aplica com relação à arbitragem, mas somente quando o Estado se submete à jurisdição de outro Estado soberano. ${ }^{4}$ Deve-se mencionar, inclusive, resolução do Instituto de Direito Internacional de 1988, que afirma que "Un État, une entreprise d'État ou une entité étatique ne peut pas invoquer son incapacité de conclure une convention d'arbitrage pour refuser de participer à l'arbitrage auquel il a consenti". 5

A celeridade representa também um fator muito positivo, em razão dos altos investimentos envolvidos nesses contratos. Ainda que o procedimento arbitral não seja em alguns casos tão rápido como se esperava, ainda será muito mais célere do que se as partes recorressem ao Judiciário. A análise deve ser, pois, comparativa. A celeridade contribui, ainda, para a diminuição dos custos. Assim, apesar de a arbitragem ser notoriamente conhecida por seus altos custos, em comparação com o que se gastaria em anos de litígio, a relação tempo versus custos ainda é positiva em favor da via arbitral.

3 Sobre arbitragem na indústria do petróleo, incluindo a análise de laudos arbitrais, decisões judiciais estrangeiras e disciplina do tema no direito brasileiro, $v$. Jacob Dolinger e Carmen Tiburcio, Arbitragem comercial internacional, Parte II, XV, Renovar, 2003, p. 441 e ss; e José Alberto Bucheb, A arbitragem internacional nos contratos da indústria do petróleo, Lumen Juris, 2002.

4 Vide Georges Delaume, State contracts and transnational arbitration, American Journal of International Law 786, 1981; e R. Luzzato, International commercial arbitration and the municipal law of states, Recueil des Cours, 157/93. Sobre o tema, veja-se Jacob Dolinger e Carmen Tiburcio, Arbitragem comercial internacional, Parte II, XIV, Renovar, 2003.

5 Fouchard, Gaillard e Goldman, Traité de l'arbitrage commercial international, 1996, p. 344. 
Sem dúvida o fato de se poder escolher especialistas da indústria do petróleo como árbitros é uma grande vantagem em relação ao processo judicial, em que o juiz deve conhecer as mais distintas áreas. De fato, juízes e tribunais, por mais capacitados que possam ser, lidam com uma variedade de matérias que vão de questões possessórias a conflitos envolvendo a interpretação de contratos de alta complexidade; passando ainda por questões familiares, ambientais, locações, leasing, dentre outras. Compreensivelmente, os membros do Poder Judiciário são, em regra, generalistas, e não especialistas. Pode-se optar, ainda, pela composição de um tribunal arbitral com advogados, engenheiros, economistas, conforme a natureza do conflito. Além disso, o tempo que o árbitro poderá destinar ao estudo do caso é muito superior ao que o juiz - por mais que quisesse - seria capaz de dedicar.

A utilização desta forma de solução de conflitos é benéfica também porque propicia maior liberdade com relação à lei aplicável ao mérito do litígio. Alguns países ainda insistem em não reconhecer às partes a autonomia da vontade para a escolha da lei aplicável ao contrato, o que torna o tema bastante controvertido quando analisado pelo Judiciário desses países. ${ }^{6}$ No campo da arbitragem, prevalece a autonomia da vontade em praticamente todos os seus aspectos, reconhecendo-se ampla liberdade para as partes escolherem a lei que melhor atenda aos seus interesses. ${ }^{7}$ As partes podem, inclusive, escolher aplicar apenas os princípios do comércio

6 No Brasil, existe controvérsia doutrinária no que se refere à possibilidade de as partes contratantes escolherem a legislação aplicável para reger os contratos internacionais. O caput do artigo $9^{\circ}$ da Lei de Introdução ao Código Civil de 1942 preceitua tão somente que, "para qualificar e reger a obrigações, aplicar-se-á a lei do país em que se constituírem". Para uma corrente da doutrina a letra da referida regra de conexão impede a aplicação da lex voluntatis: Amílcar de Castro, Direito internacional privado, $3^{\text {a }} \mathrm{ed}, 1977$, p. 411 , não admite, em qualquer caso, a autonomia da vontade. Afirma: "o direito positivo brasileiro (...) consagra a doutrina do ius loci contractus"; Irineu Strenger, Curso de direito internacional privado, 1" ed., 1978, p. 396: " $O$ princípio da autonomia da vontade foi abandonado pela Lei de Introdução atual, porque dava margem a muita controvérsia, a muita discussão"; W. S. C. Batalha, Tratado elementar de direito internacional privado, vol. II, 1960, p. 180: "Face à nova LICC não pode pairar dúvida: inaceitável é a autonomia da vontade para a indicação da lei aplicável. A autonomia da vontade só pode ser exercida no ámbito das normas dispositivas do direito reputado aplicável". Para Oscar Tenório, Direito internacional privado, vol. II, $7^{*}$ ed., 1967, p. 182, as obrigaçōes contraídas no Brasil não poderiam mais cair sob o domínio da autonomia da vontade. Segundo o autor, a liberdade das partes só seria admitida se a lei indicada pela regra de conexão brasileira permitisse a autonomia da vontade. Nåo se concorda com os autores contrários à autonomia da vontade no Direito Brasileiro, pois esta representa um dos princípios mais importantes do direito privado, não se admitindo que possa ter desaparecido pela simples omissão legislativa (no caso a Introdução ao Código Civil de 1916 previa expressamente a possibilidade de escolha e a Lei de Introdução ao Código Civil de 1942 omitiu essa possibilidade). Assim, concorda-se com a posição favorável à autonomia da vontade, na linha do que era defendido por Haroldo Valladão, Direito internacional privado, vol. II, Freitas Bastos, 1977, p. 182 e ss.

7 Art. $2^{\circ}$ da Lei: “ $A$ arbitragem poderá ser de direito ou de eqüidade, a critério das partes. $\S$ $1^{\circ}$. Poderão as partes escolher, livremente, as regras de direito que serão aplicadas na arbitragem, desde que não haja violação aos bons costumes e à ordem pública. § $2^{\circ}$. Poderão, também as partes convencionar que a arbitragem se realize com base nos principios gerais de direito, nos usos e costumes e nas regras internacionais de comércio." 
internacional (a chamada lex mercatoria), e não se restringir a uma lei estatal. ${ }^{8}$ Essa liberdade adquire fundamental importância quando o contrato de concessão é celebrado, por exemplo, com países do Oriente Médio, onde estão situadas as maiores reservas de petróleo e gás do mundo, e cujas legislações são de base religiosa e totalmente estranhas ao investidor estrangeiro.

A liberdade da arbitragem também alcança a lei aplicável ao procedimento arbitral. As partes além de poderem escolher se querem uma arbitragem institucional ou ad hoc, e as regras a serem aplicadas pelos árbitros ao procedimento arbitral, também poderão escolher a lei processual aplicável em caso de lacuna das regras escolhidas. Essa liberdade quanto à escolha da lei processual inexiste na jurisdição estatal, pois o juiz deve necessariamente aplicar a lex fori. ${ }^{9}$

Por fim, a arbitragem proporciona maior facilidade para se garantir a efetividade da decisão estrangeira, pois existem inúmeras convenções internacionais que tratam do reconhecimento e execução de laudos arbitrais estrangeiros. A principal delas é, sem dúvida, a de Nova York de 1958, que já foi ratificada por 137 países, ${ }^{10}$ inclusive pelo Brasil." A segurança do conhecimento por parte do investidor estrangeiro das regras vigentes em mais de 137 países para o reconhecimento e execução de laudos arbitrais é um grande ponto positivo em favor da utilização desta via para a solução dos litígios. O Brasil tambem é parte de outras convenções internacionais que regulam o reconhecimento de laudos arbitrais: no âmbito dos países do Mercosul devem ser atendidos os requisitos listados no Protocolo de Cooperação e Assistência Jurisdicional em Matéria Civil, Comercial, Trabalhista e Administrativa de 1992

8 Jacob Dolinger e Carmen Tiburcio, Arbitragem comercial internacional, Parte II, VII, Renovar, 2003.

9 Jacob Dolinger e Carmen Tiburcio, Arbitragem comercial internacional, Parte II, VIII, Renovar, 2003.

10 Informação obtida no site da UNCITRAL (http://www.uncitral.org/uncitral/en/uncitral_texts/arbitration/NYConvention_status.html). Acesso em 06.10.2005. Estados Ratificantes: Afeganistão, África do Sul, Albânia Alemanha, Antigua e Barbuda, Arábia Saudita, Argélia, Argentina, Armênia, Austrália, Áustria, Azerbaijão, Bahrein, Bangladesh, Barbados, Bielorrússia, Bélgica, Benin, Bolívia, Bósnia e Herzegovina, Botsuana. Brasil, Brunei, Bulgária, Burkina Faso, Camarão, Camboja, Canadá, Casaquistão, Chile, China, Chipre, Cingapura, Colômbia, Costa do Marfim. Costa Rica, Croácia, Cuba, Dinamarca, Djibuti, Dominica, Egito, El Salvador, Equador, Eslováquia, Eslovênia, Espanha, Estados Unidos, Estônia, Filipinas, Finlândia. França, Gana, Geórgia, Grécia. Guatemala, Guiné, Haiti, Holy See, Honduras, Hungria, Índia, Indonésia, Irlanda, Irã, Islândia, Israel, Itália, Iugoslávia, Jamaica, Japão, Jordânia, Kuwait, Laos, Lesoto, Letônia, Líbano, Liberia, Lituânia, Luxemburgo, Macedônia, Madagascar, Malásia, Mali, Malta, Marrocos, Maurício, Mauritânia, México, Moçambique, Moldávia, Mônaco, Mongólia, Nepal, Nicarágua, Níger, Nigéria, Noruega, Nova Zelândia, Omã, Países Baixos, Panamá, Paquistão, Paraguai, Peru, Polônia, Portugal, Qatar, Quênia, Quirquistão, Reino Unido, República Centro-Africana, República da Coréia, República Dominicana, República Tcheca, Romênia, Rússia, San Marino, São Vicente e Granadinas, Senegal, Sérvia e Montenegro, Síria, Sri Lanka, Suécia, Suiça, Tailândia, Tanzânia, Trinidad e Tobago, Tunísia, Turquia, Ucrânia, Uganda, Uruguai, Usbequistão, Venezuela, Vietnam, Zâmbia e Zimbábue.

11 Promulgada no Brasil pelo Decreto $n^{\circ} 4.311$, de 23.07.2002. 
(Protocole de Las I enã:) ${ }^{12}$ e, fora do Mercosul, há a Convenção Interamericana sobre Arbitragem Comercial Internacional de $1975^{13}$ e a Convenção Interamericana sobre Eficácia Extraterritorial de Sentenças e Laudos Arbitrais Estrangeiros de 1979..$^{14}$

\section{III - Arbitragem na Lei do Petróleo (Lei n 9.478/97)}

Há três dispositivos na Lei do Petróleo (Lei $\mathrm{n}^{\circ}$ 9.478/97) que se referem à arbitragem, seja diretamente ou através da utilização de termos correlatos, como laudo arbitral ou arbitramento: arts. 20,27, parágrafo único, e 43, inciso X. Buscaremos a seguir analisar e interpretar cada um desses dispositivos, ressaltando os seus pontos controvertidos.

a) Art. 20

$\mathrm{O}$ art. 20 da Lei do Petróleo estabelece, in verbis:

"O regimento interno da ANP disporá sobre os procedimentos a serem adotados para a solução de conflitos entre agentes econômicos, e entre estes e usuários e consumidores, com ênfase na conciliação e no arbitramento."

Alguns autores vêm defendendo que a ANP contemplou a arbitragem como mecanismo de solução dos conflitos entre agentes econômicos, e entre estes e usuários e consumidores, ao se referir a arbitramento. ${ }^{15}$

Todavia, essa interpretação implica em latente contradição com as características básicas do instituto da arbitragem. Esta, na maioria das vezes, decorre de uma cláusula compromissória inserida num contrato, segundo a qual as partes acordam em submeter as controvérsias que vierem a surgir a essa via. A arbitragem, contudo, não decorre apenas de uma relação contratual, com cláusula compromissória, podendo as partes, diante de conflito já surgido, optar pela sua utilização, através da celebração do compromisso arbitral. Entretanto, em qualquer caso, a arbitragem só pode ser instaurada após um acordo de vontade das partes, que optam por esse mecanismo alternativo de solução de controvérsias e, ao mesmo tempo, renunciam

12 Promulgada no Brasil pelo Decreto $n^{\circ} 2.067$, de 12.11.1996. Note-se que o Brasil também é parte do Acordo sobre Arbitragem Comercial Internacional do Mercosul, de 1998, promulgada pelo Decreto $n^{\circ} 4.719$, de 04.06 .2003 , que todavia não regula o reconhecimento de laudos proferidos no exterior.

13 Promulgada no Brasil pelo Decreto $\mathrm{n}^{\circ} 1.902$, de 09.05.1996.

14 Promulgada no Brasil pelo Decreto $n^{\circ} 2.411$, de 02.12.1997.

15 Essa a opinião defendida por Maria D’Assunção Costa Menezello, Comentários à lei do petróleo, Atlas, 2000 , p. 99 e ss. 
à via judicial, estatal. A arbitragem imposta, obrigatória, está em contradição com a nossa Constituição. ${ }^{16}$

Ademais, a arbitragem requer a escolha de um terceiro (um ou três árbitros), imparcial, e geralmente escolhido de comum acordo pelas partes. Assim, se no procedimento previsto no art. 20 forem nomeados árbitros funcionários da ANP, a independência exigida do julgador estará prejudicada.

O sigilo, próprio do procedimento arbitral, estaria comprometido, por ser uma arbitragem conduzida por uma agência reguladora — órgão da Administração Pública vinculado ao princípio da publicidade (art. 37, caput, da CF). ${ }^{17}$

Adicionalmente, o caráter definitivo normalmente atribuído à decisão arbitral, eis que não é sujeita a recurso ou a homologação pelo Poder Judiciário (art. 18 da Lei $\mathrm{n}^{\circ}$ 9.307/96), ficaria prejudicado com o fato de as decisões na esfera administrativa serem passíveis de revisão judicial, conforme conhecimento convencional. ${ }^{18}$

Para uma correta compreensão do sentido da norma, acreditamos ser necessário proceder à interpretação sistemática, que parece muito útil neste caso. Isso porque o art. 20 integra a seção IV da Lei, intitulada "Do processo decisório". Esta, por sua vez, faz parte do Capítulo IV da Lei, que dispõe sobre a "Agência Nacional do Petróleo". Ou seja, o art. 20 integra a seção do processo decisório da ANP. Assim, parece-nos que o art. 20 previu um mecanismo de solução de conflitos no âmbito da agência reguladora, hipótese de procedimento administrativo com características peculiares, mas que não se confunde com o instituto da arbitragem privada, tal como delineado pela Lei $n^{\circ}$ 9.307/96 (Lei de Arbitragem).

16 Sobre arbitragem obrigatória, v. Jacob Dolinger e Carmen Tiburcio, Arbitragem comercial internacional, Parte I, II e III, Renovar, 2003; e Carmen Tiburcio, Ação Direta de Inconstitucionalidade não julgada. MedProv 2.221/2001. Alteração à Lei 4.591/64. Contratos de incorporação imobiliária. Previsão legal para arbitragem obrigatória, Revista de Arbitragem e Mediação, vol. 2, 2004, p. 294 e ss.

17 Além disso, o art. 17 da própria Lei $n^{\circ}$ 9.478/97 prevê que o processo decisório da ANP obedecerá ao princípio da publicidade. $\mathrm{O}$ art. 18 estabelece ainda que as sessões deliberativas da Diretoria da ANP que se destinem a resolver pendências entre agentes econômicos e entre estes e consumidores e usuários de bens e serviços da indústria do petróleo serão públicas, permitida a sua gravação por meios eletrônicos e assegurado aos interessados o direito de delas obter transcrições. 18 Sobre a revisão dos atos decisórios das agências reguladoras pelo Poder Judiciário, confira-se lição de Marçal Justen Filho: "O primeiro ponto reside na impossibilidade de impedir ao interes. sado a faculdade de invocar a tutela jurisdicional, independentemente do exaurimento da via administrativa. Mais do que isso, a própria decisão adotada pela agência não apresenta cunho vinculante para o Judiciário, que poderá promover a ampla revisão dos atos praticados. A teoria do controle jurisdicional dos atos administrativos, segundo a configuração tradicional delineada pela doutrina e pela jurisprudência, incidirá sobre as decisões proferidas pelas agências a propósito de conflitos a ela submetidos". (Marçal Justen Filho, $O$ direito das agências reguladoras independentes, Dialética, 2002, p. 555). As resoluções conjuntas ANATEL/ANEEL/ ANP nº 01/99 e 02/01, que tratam do compartilhamento de intra-estruturas, prevêem a resolução pela Administração dos conflitos nessa esfera, com a criação de um juízo arbitral com essa finalidade. Maria Sylvia Zanella di Pietro, Parcerias da administração pública, $4^{\star 2}$ ed., Atlas, 2002, p. 384, opina que o dispositivo que prevê o seu efeito vinculante para as partes pode ser compreendido como vedação à apreciação da matéria pelo Judiciário. 
Corroborando esse entendimento, a Portaria $n^{\circ} 254$, de 11.09.2001, regulamentou procedimento de solução de conflitos de que trata o art. 58, da Lei $n^{\circ} 9.478 / 97 .^{19}$ Esse artigo dispõe que serão facultados a qualquer interessado o uso dos dutos de transporte e dos terminais marítimos existentes ou a serem construídos, mediante remuneração adequada ao titular das instalações.

A Portaria ${ }^{\circ} 254 / 01$ possui os seguintes capítulos: I- das disposições gerais; IIdas partes; III- do pedido; IV- da resposta; V- da notificação; VI- das provas; VIIda comissão especial; VIII- da resolução; IX-dos recursos; X-dos prazos; e XI- das disposições finais. Merece destaque o capítulo referente à comissão especial, que prevê que "para a análise da resolução de conflito, a Diretoria da ANP poderá designar uma Comissão Especial integrada por seus servidores" (art. 13). Dispõe, ainda, que a "Comissão Especial será composta por um mínimo de 3 (três) membros, mantendo-se sempre o número ímpar na sua formação, sendo presidida, obrigatoriamente, por um servidor da ANP, tecnicamente qualificado na matéria objeto do conflito, a quem caberáo voto de desempate" (parágrafo único). Uma vez designada, a Comissão Especial será a responsável pelo andamento do processo e pelo cumprimento de suas etapas (art. 14). No capítulo da Resolução, há a previsão de que "esgotado o prazo para as partes apresentarem suas alegações finais, a Superintendência competente da ANP ou a Comissão Especial, no prazo máximo de 30 (trinta) dias, proferirá, por escrito, sua decisão" (art. 16). Há a possibilidade de interposição de recurso da decisão, que será submetido à Diretoria da ANP, que decidirá em última instância (art. 21). ${ }^{20}$

Verifica-se, portanto, que a referida portaria regula um procedimento de solução de conflitos, com características próprias que se distinguem da arbitragem, respondendo a muitas das perguntas levantadas acima. Apesar de estar restrita ao art. 58 da Lei do Petróleo (e não haja referência na portaria ao art. 20), não há dúvidas de que se encaixa da disposição do art. 20 , sendo um importante recurso para auxiliar na sua interpretação.

Por fim, vale citar entendimento de Alexandre Freitas Câmara, contrário à prática da arbitragem pelas agências reguladoras:

"Resta, pois examinar se a agência reguladora pode se tornar uma corte arbitral (e, como previamente afirmado, a resposta a esta questão é negativa). O motivo dessa absoluta impossibilidade é, em verdade, bastante simples: a arbitragem é, por definição, uma atividade que se desenvolve à margem do Estado. É um método paraestatal (ou não-estatal) de composição de conflitos. (...) Ora, seria uma contradictio in terminis admitir que um método de resolução de conflitos alternativo ao processo estatal pudesse

19 O texto integral da Portaria $n^{\circ} 254 / 01$ está disponivel em: http://www.anp.gov.br/doc/portarias/2001/Portaria ANP 254 2001.pdf. Acesso em 28.09.2005.

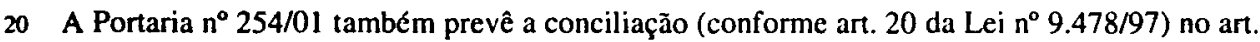
19, verbis: “Art. 19. A qualquer momento, a critério da ANP, as partes poderão ser convidadas a conciliar seus interesses, mediante convocação feita pelo Superintendente competente ou pelo Presidente da Comissão Especial". 
se desenvolver perante um órgão (...) estatal! Basta este fundamento para que se verifique o acerto da conclusão anteriormente exposta: as agências reguladoras não podem se tornar cortes arbitrais." 21

Alexandre Aragão observa que "as funções de composição de conflitos exercidas pelas autoridades reguladoras (...) não se enquadra na função arbitral em sentido estrito e próprio." 22 A possibilidade de que agências reguladoras venham a desempenhar a função de arbitramento administrativo dos conflitos também tem sido discutida em outros países. Na Espanha, a Lei n ${ }^{\circ}$ 12/97 atribui à CMT (agência regulatória espanhola na área de telecomunicações) a função de:

"Arbitrar en los conflictos que puedan surgir entre operadores de redes y servicios del sector de las telecomunicaciones y de los servicios a los que se refiere el nimero I del apartado dos de este artículo, así como en aquellos otros casos que puedan establecerse por vía reglamentaria, cuando los interesados lo acuerden.

El ejercicio de esta función arbitral no tendrá carácter público.

El procedimiento arbitral se establecerá mediante Real Decreto y se ajus. tará a los principios esenciales de audiencia, libertad de prueba, contradicción e igualdad, y será indispensable para las partes." 23

Semelhante função foi atribuída a órgãos administrativos espanhóis em matéria de: seguros (Lei $n^{\circ}$ 33/84); transporte (Lei $n^{\circ} 16 / 87$ ); arrendamento rural (Lei de 31/12/80); tráfico de produtos agrários (arbitragem do Ministério da Agricultura Lei $n^{\circ} 19 / 82$ ); setor elétrico (Lei $\left.{ }^{\circ} 12 / 97\right) .^{24}$

Demonstrando a complexidade do tema, com relação a CMT, até agora não se tem noticias de nenhuma arbitragem nos termos da Lei supracitada. ${ }^{25}$ Os conflitos têm sido resolvidos por meio de resoluções vinculantes promulgadas no exercício do poder administrativo da agência. ${ }^{26}$

21 Alexandre Freitas Câmara, Arbitragem nos conflitos envolvendo agências reguladoras, Revista de Direito, vol. XI. Direito da Regulação, Alexandre Santos de Aragão (coord.). Lumen Juris, 2002. p. 154.

22 Alexandre Aragão, Serviços públicos e concorrência, Revista de Direito Administrativo 233/311-371.

23 José Manuel Sala Arquer, La comissión del mercado de las telecomunicaciones, Cuadernos Civitas, p. 30.

24 Id: p. 31.

25 A doutrina espanhola questiona a possibilidade desse tipo de arbitragem, que não decorre da livre manifestação de vontade das partes contratantes, caracterizando-se como arbitragem imperativa e obrigatória, semelhante a um procedimento judicial. $I d$. p. 31 .

26 Id. p. 31. 
O art. 27, da Lei do Petróleo, prevê hipótese de unitização, nos seguintes termos:

"Quando se tratar de campos que se estendem por blocos vizinhos, onde atuem concessionários distintos, deverão eles celebrar acordo para individualização da produção.

Parágrafo único. Não chegando as partes a acordo, em prazo máximo fixado pela ANP, caberá a esta determinar, com base em laudo arbitral, como serão eqüitativamente apropriados os direitos e obrigações sobre os blocos, com base nos princípios gerais de Direito aplicáveis."

Marilda Rosado define unitization - ou a tradução para o português unitização - como o gerenciamento coordenado de todas ou algumas partes de um reservatório de óleo e gás pelos proprietários das áreas ou blocos situados sobre o reservatório. Segundo a autora, a literatura especializada considera que esses acordos de cooperação são frequientemente a única solução para se conseguir a recuperação máxima de um campo petrolífero através de operações eficientes e de baixo custo. ${ }^{27}$

O acordo para unitização - ou individualização como preferiu denominar a Lei do Petróleo - faz-se necessário quando um bloco de petróleo e gás está situado na fronteira entre os campos de dois concessionários vizinhos ou até entre dois países vizinhos. Nesse caso, como o óleo e o gás tendem a migrar de regiões de alto potencial para regiões de baixo potencial hidrodinâmico, se o concessionário de uma área de concessão resolver baixar o potencial hidrodinâmico de sua área, pela perfuração de poços ou pela redução da pressão de fluxo de seus poços, haverá tendência de fluxo de óleo e gás de áreas vizinhas. Tal procedimento, além de implicar numa alocação injusta da produção, pode levar o próprio reservatório a ter sérios prejuízos, reduzindo em muito a recuperação final de hidrocarbonetos do mesmo. ${ }^{28}$

A redação do dispositivo da Lei que trata da unitização não é clara e dá margem a diferentes interpretações. A interpretação literal do parágrafo único do art. 27 conduz à conclusão de que o legislador previu a arbitragem como meio capaz de resolver as controvérsias dos concessionários que não foram capazes de chegar a um acordo de individualização da produção.

Contudo, em primeiro lugar, uma leitura mais atenta do dispositivo evidencia que este não prevê que a solução definitiva será por arbitragem, mas que a ANP decidirá a questão, com base em laudo arbitral. Temos aí uma grande contradição com uma das principais características do instituto da arbitragem, que é a de que os árbitros proferem uma decisão final e vinculante para as partes - a sentença arbitral

27 Marilda Rosado de Sá Ribeiro, Direito do petróleo: as joint ventures na indústria do petróleo, 2* ed., Renovar, 2003, p. 186.

28 Valéria T. Appi e Gersen M. Andrade, apud Marilda Rosado de Sá Ribeiro, Direito do petróleo: as joint ventures na indústria do petróleo, 2 ed., Renovar, 2003, p. 188. 
—, que não está sujeita a recurso ou a homologação pelo Poder Judiciário, nos termos do art. 18 da Lei de Arbitragem. ${ }^{29}$ No mecanismo previsto no dispositivo em análise, a decisão final caberá à ANP, e não à arbitragem.

Algumas perguntas inevitavelmente se colocam. Qual será a finalidade do laudo arbitral, uma vez que a ANP aparentemente não estará vinculada a ele? Poderão ser nomeados árbitros independentes ou os árbitros deverão integrar o corpo técnico da própria ANP? Caso os árbitros integrem o corpo técnico da ANP, não estaria comprometida a neutralidade do julgador - outra grande característica da arbitragem? O dispositivo não estaria criando um duplo mecanismo decisório - arbitragem e decisão pela ANP -, gerando altos custos para as partes envolvidas? E se a ANP se valer da sua independência e discricionariedade e não acatar a decisão dos árbitros, os altos custos da arbitragem terão sido em vão?

Além disso, como poderia o parágrafo único do art. 27 prever a utilização da arbitragem entre dois concessionários que nem mesmo possuem uma relação contratual entre eles (o contrato é celebrado entre cada um deles e a ANP)? Com base nesse questionamento, José Alberto Bucheb defende a inconstitucionalidade do dispositivo. ${ }^{30}$

Diversamente, preferimos salvar o dispositivo, adotando uma interpretação conforme a Constituição, ${ }^{31}$ e vislumbrar uma espécie de mecanismo decisório no

29 Lei $n^{\circ}$ 9.307/96: "Art.18. O árbitro é juiz de fato e de direito, e a sentença que proferir não fica sujeita a recurso ou a homologação pelo Poder Judiciário."

30 José Alberto Bucheb, A arbitragem internacional nos contratos da indústria do petróleo, Lumen Juris, 2002, p. 31: "Trata-se aqui de uma hipótese sui generis de solução de controvérsias pela via arbitral, em que não existe a cláusula compromissória porque não há vínculo contratual entre os concessionários dos blocos contíguos pelos quais se estende a jazida a ser objeto de individualização da produção de petróleo, mas sim contratos distintos, celebrados por cada concessionário com o poder concedente, neste caso a União, representada pela ANP, e em que o compromisso arbitral será imposto por terceiro, a ANP, respaldada para tanto pela lei e pelo Contrato de Concessão.

Sustentamos a inconstitucionalidade do parágrafo único do art. 27 da Lei $n^{\circ}$ 9.478/97 e, consequientemente, a inaplicabilidade do parágrafo 12.1 .4 da primeira versão do Contrato de Concessão brasileiro, pelas razões a seguir expostas." (destaque acrescentado)

31 Sobre a interpretação conforme a Constituição, confira-se lição de Luís Roberto Barroso: " $A$ interpretação conforme a Constituição compreende sutilezas que se escondem por trás da designação truística do princípio. Cuida-se, por certo, da escolha de uma linha de interpretação de uma norma legal, em meio a outras que o Texto comportaria. Mas, se fosse somente isso, ela não se distinguiria da mera presunção de constitucionalidade dos atos legislativos, que também impõe o aproveitamento da norma sempre que possivel. O conceito sugere mais: a necessidade de buscar uma interpretação que não seja a que decorre da leitura mais óbvia do dispositivo. É, ainda, da sua natureza excluir a interpretação ou as interpretações que contravenham a Constituição. $\grave{A}$ vista das dimensōes diversas que sua formulação comporta, é possível e conveniente decompor didaticamente o processo de interpretação conforme a Constituiçāo nos elementos seguintes: 1) Trata-se da escolha de uma interpretação da norma legal que a mantenha em harmonia com a Constituição, em meio a outra ou outras possibilidades interpretativas que o preceito admita. 2) Tal interpretação busca encontrar um sentido possivel para a norma, que não é o que mais evidentemente resulta da leitura de seu texto. 3) Além da eleição de uma linha de interpretação, procede-se à exchusão expressa de outra ou outras interpretações posstveis, que conduziriam a resultado contrastante 
âmbito da própria agência reguladora, que se basearia para formar seu convencimento numa espécie de laudo pericial (erroneamente denominado laudo arbitral). Assim, poder-se-ia entender que a ANP se valerá da ajuda de um perito, que avaliará todas as questões técnicas envolvidas na individualização da produção, e proferirá um laudo pericial, que poderá ser seguido ou não pela ANP. ${ }^{32}$

Reconhece-se a intenção do legislador de buscar uma solução alternativa para quando as partes não conseguirem chegar sozinhas a um acordo. Mas, o fato é que o objetivo do dispositivo não ficou claro e, além disso, é preciso compatibilizá-lo com o nosso sistema e com a nossa Constituição.

A questão é complexa e ainda inédita no Brasil. Por essa razão, não se pretende no presente trabalho oferecer uma solução definitiva. Buscou-se tão-somente levantar algumas questões polêmicas para enriquecer o debate. Talvez em breve venhamos a nos deparar com a hipótese de unitização, em razão da diminuição do tamanho das áreas ofertadas na sexta rodada da ANP, e o mecanismo previsto no parágrafo único do art. 27 tenha que ser aplicado.

c) Art. 43, inciso $X$

$\mathrm{O}$ art. 43, inciso X, da Lei do Petróleo, prevê a arbitragem como cláusula essencial do contrato de concessão para exploração e produção de petróleo e gás. Confira-se a dicção do dispositivo:

"Art. 43. O contrato de concessão deverá refletir fielmente as condiçōes do edital e da proposta vencedora e terá como cláusulas essenciais:

com a Constituição. 4) Por via de conseqüência, a interpretaçāo conforme a Constituição não é mero preceito hermenêutico, mas, também, um mecanismo de controle de constitucionalidade pelo qual se declara ilegítima uma determinada leitura da norma legal." (Luís Roberto Barroso, Interpretação e aplicação da Constituição: fundamentos de uma dogmática constitucional transformadora, 5 ed., Saraiva, 2003, p. 188-189).

32 No mesmo sentido, confira-se entendimento de Selma Lemes:" Verificamos que apesar de o artigo [27, parágrafo único da Lei do Petróleo] mencionar que a decisāo da ANP será respaldada em 'laudo arbitral', na verdade, está a se referir à figura do arbitramento e não da arbitragem. $O$ que instruirá a decisão da ANP é um parecer técnico e não uma sentença arbitral. (...) o arbitrador ou perito emite opinião sobre matéria de fato cuja finalidade é servir, auxiliar e informar o juiz ou julgador; não resolve a controvérsia." Selma M. Ferreira Lemes, A arbitragem e os novos rumos empreendidos na administração pública. A empresa estatal, o estado e a concessāo de serviço público. In: Aspectos fundamentais da lei de arbitragem, Pedro A. Batista Martins, Selma M. Ferreira Lemes e Carlos Alberto Carmona, Forense, 1999, p. 204. A autora defende ainda que nem mesmo a Resolução Conjunta n $2 / 01$ prevê hipótese de arbitragem, mas tão-somente de uma decisão administrativa: "Note-se que a Resolução $n^{\circ}$ 02, de 27.03.01, que dispãe sobre a resolução de conflitos das Agências Reguladoras dos setores de Energia Elétrica, Telecomunicaçōes e Petrółeo referente ao compartilhamento de infra-estrutura não se trata de arbitragem, mas de decisão administrativa, não obstante mencionar que a decisão exarada em seu âmbito tenha caráter vinculante." (Selma Maria Ferreira Lemes, Arbitragem na concessão de serviço público - perspectivas. In: Estudos em Arbitragem, Mediação e Negociação, André Gomma de Azevedo (org.). Brasilia Jurídica, 2002, p. 53). 
$X$ - as regras sobre solução de controvérsias, relacionadas com o contrato e sua execução, inclusive a conciliação e a arbitragem internacional."

\section{Arbitragem Internacional}

Em consonância com a prática internacional, o legislador brasileiro contemplou a arbitragem como cláusula essencial do contrato de concessão. Contudo, algumas questões surgem a partir de uma análise mais detalhada desse dispositivo.

Em primeiro lugar, verifica-se que o inciso $X$ contempla não somente a arbitragem, mas a arbitragem internacional. O conceito de arbitragem internacional não está expresso na nossa legislação (Lei $n^{\circ} 9.307 / 96$ - Lei de Arbitragem), mas pode ser inferido da redação do parágrafo único do art. $34 .{ }^{33}$ Segundo esse dispositivo, considera-se sentença arbitral estrangeira aquela proferida fora do território nacional. Daí conclui-se que o legislador brasileiro adotou o critério geográfico como definidor da nacionalidade da sentença arbitral. Se sentença arbitral estrangeira é aquela proferida fora do território nacional, então arbitragem estrangeira é aquela que tem sede fora do território nacional. A conclusão parece lógica.

Voltando à Lei do Petróleo, indaga-se se o objetivo da Lei foi delimitar as hipóteses de arbitragem decorrentes de controvérsias dos contratos de concessão de exploração e produção de petróleo e gás a arbitragens internacionais, ou seja, arbitragens com sede em outros países. Não parece ter sido essa a intenção do legislador. A melhor interpretação é a que entende que se a Lei previu até a arbitragem internacional, com mais razão admitiu a arbitragem nacional. ${ }^{34}$

33 Lei $n^{\circ}$ 9.307/96: “Art. 34. (...) Parágrafo único: Considera-se sentença arbitral estrangeira a que tenha sido proferida fora do território nacional."

34 Nesse sentido, confira-se a opinião de Pedro Batista Martins: "Essa imprecisão legislativa é também fonte de dúvidas nos contratos de exploração de petróleo, dado que a Lei $n^{\circ}$ 9.478/97 somente se reporta à arbitragem internacional.Temos, entretanto, que essa incerteza não se sustenta: a arbitragem interna também vale na solução de disputas oriundas de contratos administrativos que tenham por objeto a exploração de petróleo. (...)O intérprete há de convir que o legislador, a par da possibilidade de se resolverem as controvérsias por arbitragem interna, optou por deixar expressa, também, a validade da arbitragem internacional, até mesmo pela natureza peculiar do negócio e da qualificação de seus partícipes. Entendimento reverso consubstanciaria subversão da ordem jurídica em que hoje, como vimos, se assenta a doutrina e a jurisprudência." Pedro Batista Martins, O Poder Judiciário e a arbitragem: quatro anos da Lei $n^{\circ}$ 9.307/96 (3" Parte), Revista Forense 359/165, p. 177. Note-se que os laudos arbitrais famosos da indústria do petróleo foram proferidos em arbitragens internacionais (sede da arbitragem localizada em um país neutro com ampla tradição em arbitragem, como França ou Suíça). Por exemplo, no caso Kuwait v. Aminoil, a sede da arbitragem foi Paris; no caso Aramco (Arabian American Oil Co. v. Arábia Saudita), a sede foi na Suíça; no caso Sapphire International Petroleums Limited v. National Iranian Oil Company (NIOC), a sede da arbitragem foi também na Suíça. Sobre esses casos, v. Jacob Dolinger e Carmen Tiburcio, Arbitragem comercial internacional, Parte II, XV, Renovar, 2003, p. 443 e ss. 
O dispositivo prevê como cláusula essencial do contrato de concessão a que disponha sobre as regras de solução de controvérsias, inclusive a conciliação e a arbitragem internacional. A palavra "inclusive", ao mesmo tempo em que põe fim a qualquer posição que vislumbrasse uma hipótese de arbitragem obrigatória, vedada pela Constituição, eis que não prevê a arbitragem como o único mecanismo de solução de controvérsias, ${ }^{35}$ dá origem ao debate sobre a coexistência das cláusulas de eleição de foro e arbitral num mesmo contrato. Explica-se.

As cláusulas de eleição de foro e arbitral possuem a mesma finalidade: estabelecer a forma de solução das disputas decorrentes do contrato em que estão inseridas. A cláusula de eleição de foro representa a escolha da jurisdição comum, ou seja, as partes optam pela via tradicional, estatal, de solução de disputas. ${ }^{36}$ Por outro lado, as partes podem preferir uma via alternativa de solução de controvérsias e optar, por exemplo, pela arbitragem.

Assim, as duas cláusulas são, a princípio, conflitantes, opostas, e a coexistência de ambas num mesmo contrato pode levar à invalidação de uma delas ${ }^{37}$ Como a arbitragem representa exceção à jurisdição comum, estatal, a cláusula arbitral pode facilmente vir a ser desconsiderada em caso de conflito. ${ }^{38} \mathrm{~A}$ única possibilidade de

35 Adota-se também aqui a interpretação conforme a Constituição, no sentido de que a Lei, ao prever a arbitragem como forma de solução dos conflitos decorrentes dos contratos de exploração e produção de petróleo, determinou que os litígios, a critério das partes, podem vir a ser dirimidos por arbitragem e não que necessariamente tenham que ser dirimidos por esta via. Nesse ponto, a posição aqui adotada representa uma ligeira evolução daquela manifestada na obra Arbitragem Comercial Internacional (v. p. 461), onde se partiu do entendimento que o art. 43 da Lei do Petróleo determina que todos os litígios decorrentes dos contratos de concessão de E\&P devem ser dirimidos por arbitragem. Como esse entendimento apresenta problemas de compatibilidade com a Constituição Federal, eis que determina a arbitragem obrigatória, concluiu-se que a posição aqui defendida é a melhor: o art. 43 não determina que todas as controvérsias devem ser solucionadas por arbitragem, mas que o administrador está autorizado a clausular a arbitragem nesses contratos.

36 Sobre a cláusula de eleição de foro e sua aceitação pelos tribunais brasileiros, v. Carmen Tiburcio, Três temas de processo internacional, Revista dos Tribunais 794/159.

37 Vale transcrever crítica feita por Pedro Batista Martins a esse dispositivo, no que se refere à coexistência das cláusulas arbitral e de eleição de foro num mesmo contrato: "Não foi de boa técnica legislativa impor aos contratantes, conjuntamente, a disposição do foro e do modo de solução amigável das controvérsias. (...) Por certo, esse amálgama é de todo indesejável e sofre censura severa dos estudiosos. A fixação de foro não se coaduna com a cláusula arbitral, exceto se ressalvada expressamente sua finalidade: casos de revisão da decisão arbitral; imposição de medidas cautelares ou coercitivas; análise das questões contratuais inarbitráveis. Mas isso o legislador não fez! E, ao não usar da boa técnica, com certeza acabará por induzir os entes públicos a estabelecer cláusulas compromissórias a merecer interpretação pragmática por parte dos julgadores." Pedro Batista Martins, O Poder Judiciário e a arbitragem: quatro anos da Lei $n^{\circ} 9.307 / 96$ ( $3^{a}$ Parte), Revista Forense 359/165, p. 176-177.

38 A título exemplificativo, note-se que a decisão proferida em 1999, pelo juiz da $28^{2}$ Vara Cível do Rio de Janeiro, julgou improcedente a pretensão da autora de instauração do juízo arbitral, em virtude da coexistência das cláusulas de eleição de foro e arbitral. Em sentido contrário, v. decisão 
convivência entre as duas cláusulas num mesmo contrato ocorre quando elas são redigidas com extrema cautela, delimitando-se de forma precisa o escopo de cada uma. Por exemplo, pode-se determinar que nas hipóteses em que for necessária a intervenção do Poder Judiciário, em razão de a questão estar fora da competência dos árbitros, as partes desde já elegem um determinado foro como competente. Busca-se com esse mecanismo afastar qualquer insegurança ou indefinição quanto ao meio de solução de controvérsias. ${ }^{39}$

Todavia, mesmo na hipótese de as duas cláusulas - a de eleição de foro e a arbitral - estarem bem delimitadas no contrato, podem surgir alguns problemas. Por exemplo, caso as partes tenham escolhido o foro da cidade de São Paulo para decidir as questões que não puderem ser resolvidas por arbitragem, e venham a precisar de uma medida cautelar antes da instauração da arbitragem para apreensão de determinado bem móvel situado no Rio de Janeiro. Pode-se facilmente entender que a escolha do foro também se aplica às medidas cautelares e que, portanto, o único juiz competente para conceder a medida é o juiz de São Paulo. A necessidade do provimento de urgência estará em risco pela demora no cumprimento da carta precatória. Esse é apenas um exemplo do tipo de problema que pode advir da coexistência das duas cláusulas num mesmo contrato.

A melhor interpretação para o dispositivo é, sem dúvida, a que entende que o legislador, ao contemplar a arbitragem, criou apenas uma autorização para a adoção dessa via de solução de controvérsias pela Administração Pública (no caso, a ANP), em respeito ao princípio da legalidade. Isso porque, de acordo com o entendimento de parte substancial da doutrina, a utilização da arbitragem pelo Estado e por entes da Administração Pública só é possível se houver lei autorizativa. ${ }^{40}$

inovadora do Tribunal de Justiça do Estado de São Paulo, no Agravo de Instrumento ${ }^{\circ}$ 124.217.4/0, em que se privilegiou a cláusula compromissória, em detrimento da cláusula de eleição de foro também presente no contrato. Sobre essas decisões, v. Jacob Dolinger e Carmen Tiburcio, Arbitragem comercial internacional, Parte II, I, Renovar, 2003, p. 168-169.

39 Eros Roberto Grau, em parecer sobre a arbitrabilidade de litígios envolvendo sociedades de economia mista, sustenta a compatibilidade entre as cláusulas de eleição de foro e arbitral: "(...) em que medida a eleiçāo de foro seria incompatível com a cláusula que prevê a arbitragem? Tenho como evidente, no caso, a circunstância de a cláusula de eleição de foro dirigir-se a situações que nāo possam sujeitar-se à arbitragem. De outro lado, a cláusula de foro fixa a competência para a i) execução do julgado arbitral, ii) ação de nulidade da arbitragem ou iii) formulação dos pedidos a que se refere o art. $22, \S \S 2^{\circ}$ e $4^{\circ}$, da Lei 9.307, de 1996. Para logo se vê, destarte, que, longe de consubstanciar incompatibilidade, essas cláusulas se complementam e têm por objetivo conferir o maior grau de efetividade possivel ao sistema de resolução de conflitos que surgirem a respeito do contrato celebrado." (Eros Roberto Grau, Da arbitrabilidade de litígios envolvendo sociedades de economia mista e da interpretação de cláusula compromissória, Revista de Direito Bancário, do Mercado de Capitais e da Arbitragem 18/395, p. 404-405). Entretanto, o argumento do ilustre administrativista quanto ao item ii não se sustenta, pois é regra assente no direito internacional que a ação de nulidade do laudo só pode ser proposta perante o judiciário da sede da arbitragem. Vide Jacob Dolinger e Carmen Tiburcio, Arbitragem comercial internacional, Parte II, XIII, Renovar, 2003.

40 Sobre o tema, vide: Jacob Dolinger e Carmen Tiburcio, Arbitragem comercial internacional, Parte II - XIV Arbitragem envolvendo o Estado e Entes da Administração Pública, Rio de Janeiro: 
Nos termos do art. 37, caput, da Constituição de 1988, a Administração Pública, direta e indireta, deve pautar sua atuação no princípio da legalidade, que significa que esta somente pode fazer aquilo que não é vedado pela lei - princípio da legalidade aplicável aos particulares - mas também só pode fazer aquilo que é expressamente permitido por lei. Dessa forma, por ser necessária a existência de lei autorizando a submissão à arbitragem, nos últimos anos, algumas leis foram editadas contendo essa autorização. Como exemplo pode-se citar a Lei $n^{\circ} 5.662$, de 1971 (BNDES), art. $5^{\circ}$; o Decreto-lei $\mathrm{n}^{\circ} 1.312 / 74$ (Tesouro Nacional), art. 11; a Lei $\mathrm{n}^{\circ}$ 8.987/95 (Lei de Concessões), art. 23, inciso XV; a Lei $n^{\circ}$ 9.472/97 (Lei Geral de Telecomunicações), art. 93, XV; a Lei $n^{\circ} 10.848 / 04$ (CCEE), art. $4^{\circ}, \S 6^{\circ}$ e a Lei ${ }^{\circ}$ 11.079/04 (PPP), art. 11.

\section{Contrato de Adesão}

Cabe uma última observação com relação a esse dispositivo. Há quem defenda a atribuição de efeitos especiais à cláusula compromissória dos contratos de concessão das rodadas de licitação da ANP, por considerarem que esse contrato é um contrato de adesão. Dessa forma, busca-se a aplicação da regra prevista no art. $4^{\circ}$, da Lei $n^{\circ}$ 9.307/96 (Lei de Arbitragem), segundo a qual, "nos contratos de adesão, a cláusula compromissória só terá eficácia se o aderente tomar a iniciativa de instituir a arbitragem ou concordar, expressamente, com a sua instituição, desde que por escrito em documento anexo ou em negrito, com a assinatura ou visto especialmente para essa cláusula". 11

A rigor, trata-se, portanto, de dois requisitos impostos à eficácia da cláusula arbitral nos contratos de adesão: (i) a cláusula deve estar em documento anexo ao contrato ou em negrito no próprio contrato, com assinatura ou visto especialmente para ela; (ii) a instauração da arbitragem só é válida se proposta pela parte aderente. A par da controvérsia existente sobre a necessidade de cumulação desses dois

Renovar, 2003; Suzana Domingues Medeiros, Arbitragem envolvendo o Estado no direito brasileiro, Revista de Direito Administrativo, Rio de Janeiro, v. 233, jul./set. 2003; Luís Roberto Barroso, Sociedade de economia mista prestadora de serviço público. Cláusula arbitral inserida em contrato administrativo sem prévia autorização legal. Invalidade. In: Temas de direito constitucional, Luís Roberto Barroso, tomo II, 2003, p. 620.

41 Essa é a opinião de José Alberto Bucheb: "Deve-se observar ainda que o Contrato para Exploraçāo, Desenvolvimento e Produção de Petróleo e Gás Natural pode ser caracterizado como um contrato de adesão, em sentido amplo. (...) Assim, nos termos do $\S 2^{\circ}$ do art. $4^{\circ}$ da Lei $n^{\circ}$ 9.307/96, a cláusula compromissória só terá eficácia se o aderente, no caso o concessionário, tomar a iniciativa de instituir a arbitragem ou concordar, expressamente, com a sua instituiçāo. Ainda que, com toda probabilidade, a intenção, ao incluir este dispositivo na Lei de Arbitragem, tenha sido tão somente o de proteger o consumidor, em conformidade com a definição de contrato de adesão explicitada no art. 54 da Lei $n^{\circ}$ 8.078/90 (Código de Defesa do Consumidor), a hipótese de sua incidência sobre os contratos administrativos, em particular os contratos de concessão para exploração, desenvolvimento e produção de petróleo e gás natural, não pode ser afastada, já que os mesmos se enquadram perfeitamente na espécie, como destacado acima." José Alberto Bucheb, A arbitragem internacional nos contratos da indústria do petróleo, Lumen Juris, 2002, p. 37-40. 
requisitos, o fato é que esse dispositivo retira da cláusula compromissória a eficácia plena atribuída por outros dispositivos da Lei de Arbitragem. Sua aplicação, a nosso ver, só se justifica nos casos de contratos de adesão em que uma das partes é hipossuficiente e precisa dessa proteção criada pela lei. Discordamos, portanto, da posição que defende a extensão da regra do art. $4^{\circ}, \S 2^{\circ}$, da Lei de Arbitragem aos contratos de concessão de petróleo e gás, pois acreditamos que esse dispositivo se destina somente às cláusulas compromissórias constantes de contratos em que há uma parte economicamente mais fraca, como normalmente ocorre nos contratos de consumo.

Não obstante poder ser o contrato de concessão para exploração e produção de petróleo e gás considerado um contrato de adesão, eis que elaborado pela ANP unilateralmente, com pouca margem de negociação para o concessionário (só nas audiências públicas realizadas pela ANP previamente a cada rodada de licitação), não vemos como caracterizar as empresas concessionárias como hipossuficientes. Essas são empresas internacionais, de grande porte, que, em regra, atuam em licitações em diversos países que possuem reservas de petróleo e gás natural, e que estão amplamente familiarizadas com a prática da arbitragem e até a preferem. Como aqui já se comentou, tais empresas relutam em aceitar que tais disputas sejam decididas pelo Judiciário do país hospedeiro e, portanto, a cláusula compromissória é uma exigência do negócio. Assim, não vemos como possa uma dessas grandes empresas da indústria do petróleo alegar a regra contida no art. $4^{\circ}, \S 2^{\circ}$, da Lei de Arbitragem, para tentar fugir da arbitragem. ${ }^{42}$

\section{Conciliação}

$O$ art. 43, inciso $X$, da Lei do Petróleo, contempla também a conciliação como cláusula essencial do contrato de concessão. A conciliação, todavia, não suscita as controvérsias apresentadas com relação à arbitragem, pois, ao contrário da arbitragem, ${ }^{43}$ não impede que as partes recorram a um outro método caso não consigam

42 A título ilustrativo, as empresas que ganharam a terceira, quarta, quinta e sexta rodadas de licitação: (i) terceira rodada foram as seguintes: Amerada Hess, El Paso, Enterprise, Esso, Ipiranga, Kerr-McGee, Koch, Maersk, Ocean, PanCanadian, Petrobras, Petrogal, Petroserv, Phillips, Queiroz Galvão, Rainier, Repsol-YPF, Samson, Shell, Statoil, Total Fina Elf e Wintershall; (ii) quarta rodada: BHP Billiton, Devon Energy, Dover, El Paso, Maersk, Newfield, Partex, Petrobras, PetroRecôncavo, Queiroz Galvão, Shell, Starfish, Statoil e Unocal; (iii) quinta rodada: Aurizônia Empreendimentos Ltda., Maersk Olie og Gas AS, Newfield Exploration Company, Partex Oil and Gas (Holdings) Corporation, Petrobras e Synergy Group Corp. (iv) sexta rodada: Arbi Petróleo Ltda., Aurizônia Empreendimentos Lida., Devon Energy Corporation, EnCana Corporation, Epic Gás International Serviços do Brasil Ltda., Kerr-McGee Corporation, Partex Oil and Gás (Holdings) Corporation, Petróleo Brasileiro S.A., Petróleos de Portugal - Petrogal S.A., PetroRecôncavo S.A., PortSea Oil \& Gás NL, Queiroz Galvão Perfurações S.A., Repsol YPF Brasil S.A., Shell Brasil S.A., SK Corporation, Starfish Oil \& Gás S.A., Statoil ASA, Synergy Group Corp, W. Washington Empreendimentos e Participações. (http://www.brasil-rounds.gov.br/geral/RESUMO geral.asp. Acesso em 28.09.2005).

43 Como visto, as cláusulas arbitral e de eleição de foro se prestam à mesma finalidade e, portanto. 
chegar a um acordo. A conciliação é comumente tratada como uma fase prévia à solução jurisdicional - judicial ou arbitral. Caso as partes cheguem a um acordo na conciliação, não será necessário o recurso à arbitragem ou à jurisdição estatal.

A par da controvérsia existente entre a terminologia conciliação ou mediação, ${ }^{44}$ este método alternativo de solução de disputas consiste, segundo definição de Leonard L. Riskin, num processo no qual um terceiro imparcial ajuda as partes a resolverem a disputa ou a planejarem uma transação. Trata-se, portanto, de uma negociação facilitada, que implica necessariamente na intervenção de um terceiro. ${ }^{45}$ O legislador quis, assim, privilegiar esse método alternativo de solução de disputas que vem ganhando importância em todo o mundo.

são opostas. É corrente que se as partes escolhem o juízo arbitral (através da cláusula compromissória), este se impõe como o único mecanismo de solução de controvérsias possível, não podendo qualquer delas unilateralmente desistir da arbitragem e recorrer ao Poder Judiciário (na Lei de Arbitragem brasileira, a plena eficácia da cláusula compromissória foi reconhecida pelos arts. $5^{\circ}$ e $7^{\circ}$ ). Adicionalmente, após proferido o laudo arbitral, as partes não podem recorrer ao Poder Judiciário para buscar um novo julgamento sobre a mesma matéria ou uma revisão de mérito do laudo arbitral. O recurso ao Poder Judiciário só é possível nas hipóteses de nulidade, taxativamente previstas no art. 32 da Lei $n^{\circ} 9.307 / 96$.

44 Amom Albernaz Pires, em estudo sobre a possível distinçâo entre as denominações mediação e conciliação, conclui: "Conforme demonstrado, só há razões suficientes a autorizar uma diferenciação conceitual entre a mediação e a conciliação praticada no Judiciário brasileiro em termos de gênero comum e gênero processual-legal, respectivamente, pois ambos institutos constituem. em última análise, a mesma coisa, com a exceção de medią̧ão ser gênero comum a todas as situações compatíveis com o conceito amplo de mediação, ao passo que conciliação é o nome específico que a medią̧ão, como gênero comum, recebe uma vez inserida no âmbito processuallegal." O autor aponta que, apesar de o termo mediação ser mais apropriado e consentâneo com a prática internacional, a nossa legislação, na maioria das vezes, optou pelo termo conciliação. Assim, o autor cita os seguintes diplomas que se referem à conciliação: Constituição Federal de 1988, art. 98, I e art. 114, caput (competência para conciliação aos Juizados Especiais Cíveis e Criminais e à Justiça do Trabalho, respectivamente); o Código de Processo Civil de 1973 possui diversos dispositivos que se referem à conciliação, como por exemplo, os arts. 447-449 (tentativa de conciliação no início da fase de instrução e julgamento, renovando-lhes a oportunidade de conciliação conforme art. 331) e o art. 125, IV (dever do juiz de tentar a qualquer momento a conciliação entre as partes); Lei de Arbitragem (Lei $n^{\circ}$ 9.307/96), art. 21, $\$ 4^{\circ}$, e art. 28 (tentativa de conciliação pelo árbitro ou o tribunal no início do procedimento arbitral, sendo que se as partes chegarem a um acordo, o árbitro ou o tribunal poderá, a pedido das partes, declarar tal fato mediante sentença arbitral); Lei $n^{\circ}$ 9.099/95, arts. 22 e 60 (competência dos juizados especiais para realizar a conciliação); CLT (consagra a conciliação na fase de instrução dos dissídios individuais e coletivos); Lei $n^{\circ}$ 9.958/2000 (criou as comissões de conciliação prévia no âmbito da justiça do trabalho). Segundo o autor, apenas as Leis $n^{\circ} 10.101 / 2000$ (art. $4^{\circ}$ ) e 10.192/2001 (art. 11) referem-se à mediação, e não mais à conciliação. Essas leis versam sobre conflitos em que uma das partes é trabalhadora e preceituam a intervenção de um mediador para conduzir a negociação coletiva. (Amom Albernaz Pires, Mediação e conciliação: breves reflexões para uma conceituação adequa. da. In: Estudos em Arbitragem, Mediação e Negociação, André Gomma de Azevedo (org.), Brasília Jurídica, 2002, p. 135 e ss.

45 Leonard L. Riskin, Compreendendo as orientaçōes, estratégias e técnicas do mediador: um padrão para iniciantes. In: Estudos em Arbitragem, Mediação e Negociação, André Gomma de Azevedo (org.), Brasília Jurídica, 2002, p. 70. 
O que não ficou claro, todavia, é como essa conciliação será realizada, ou melhor, quem será o conciliador. O conciliador será a própria ANP (eis que o art. 20 já contemplou a conciliação no âmbito do processo decisório da agência) ou será feita por um terceiro independente e imparcial, por exemplo, um especialista da indústria do petróleo? A segunda opção seria mais desejável no caso dos contratos de concessão por primar pela imparcialidade do conciliador.

\section{IV - Arbitragem nos Contratos de Concessão das Rodadas de Licitação da ANP}

Após ter analisado os artigos da Lei do Petróleo que se referem - ao menos aparentemente - à arbitragem, passaremos à análise das cláusulas de conciliação, arbitragem e eleição de foro dos contratos de concessão da rodada zero, e da primeira, segunda, terceira, quarta, quinta e sexta rodadas de licitação realizadas até o momento pela Agência Nacional do Petróleo, bem como o contrato de concessão da sétima rodada. ${ }^{46}$

\section{a) Rodada zero}

A primeira rodada, a rodada zero, realizou-se em 1998, e contou apenas com a participação da Petrobrás, em cumprimento ao disposto no art. 34 da Lei ${ }^{\circ}$ 9.478/97, que previu que dentro do prazo de um ano a partir da data da publicação da lei, a ANP celebraria com a Petrobras, com dispensa de licitação, contratos de concessão dos blocos que possuam campos em efetiva produção (art. 32) ou que já tivessem sido realizadas descobertas comerciais ou tivessem sido promovidos investimentos na exploração (art. 33).

A cláusula de eleição de foro, conciliação e arbitragem pertenciam à cláusula vigésima nona, intitulada "Regime Jurídico", ${ }^{47}$ e possuíam a seguinte redação:

$46 \mathrm{O}$ art. $8^{\circ}$, inciso IV, conferiu essa atribuição à ANP, ao dispor que: "A ANP terá como finalidade promover a regulação, a contratação e a fiscalização das atividades econômicas integrantes da indústria do petróleo, cabendo-lhe: IV - elaborar os editais e promover as licitaçōes para a concessão de exploração, desenvolvimento e produção, celebrando os contratos delas decorrentes e fiscalizando a sua execução". Além disso, o art. 21 prevê que todos os direitos de exploração e produção de petróleo e gás natural em território nacional, nele compreendidos a parte terrestre, $o$ mar territorial, a plataforma continental e a zona econômica exclusiva, pertencem à União, cabendo sua administração à ANP. Para uma breve análise das cláusulas de arbitragem dos contratos de concessão para exploração e produção de petróleo, v. Suzana Domingues Medeiros, Arbitragem nos contratos de E\&P de petróleo, Revista da Câmara de Comércio Americana do Rio de Janeiro, $\mathrm{n}^{\circ} 194$, nov./ 2003, p. 48-49.

47 Em todas as outras rodadas as cláusulas de eleição de foro, conciliação e arbitragem continuaram integrando a cláusula do regime jurídico. Critica-se essa localização, pois essas cláusulas referem-se a solução de controvérsias e não a regime jurídico (que deveria ser integrada apenas pela cláusula de lei aplicável). 
“Cláusula Vigésima-Nona - Regime Jurídico

(...)

Foro

29.2 Fica eleito o foro da Cidade do Rio de Janeiro para resolver quaisquer dúvidas, controvérsias, conflitos ou pendências surgidos entre as partes em decorrência da execução ou da interpretação deste Contrato, que não possam ser solucionados de forma amigável ou por meio de arbitragem.

Conciliação

29.3 As Partes envidarão todos os esforços no sentido de resolver entre si, amigavelmente, toda e qualquer disputa ou controvérsia decorrente deste Contrato ou com ele relacionada. Poderão também, desde que firmem acordo unânime por escrito, recorrer a perito internacional, para dele obter um parecer fundamentado que possa levar à superação da disputa ou controvérsia.

29.3.1 Firmado um acordo para a intervenção de perito internacional, nos termos do parágrafo 29.3, o recurso à arbitragem, previsto no parágrafo 29.4, somente poderá ser exercido depois que esse perito tiver emitido seu parecer fundamentado.

\section{Arbitragem}

29.4 Observado o disposto no parágrafo 29.3.1, se a qualquer momento uma parte considerar que inexistem condições para uma solução amigável de uma disputa ou controvérsia a que se refere o parágrafo 29.3, então essa parte poderá submeter essa disputa ou controvérsia à arbitragem, dando inicio ao processo respectivo, de acordo com os seguintes princípios:

(a) serão três os árbitros, escolhidos um por cada Parte e o terceiro, que exercerá as funções de presidente, nomeado de acordo com as Regras especificadas na letra $(d)$;

(b) o lugar da arbitragem será a cidade do Rio de Janeiro, Estado do Rio de Janeiro, Brasil;

(c) o idioma a ser utilizado no processo de arbitragem será a língua portuguesa, podendo os árbitros, por unanimidade, aceitar depoimentos ou documentos em outro idioma, sem necessidade de tradução oficial;

(d) a arbitragem se realizará de acordo com as Regras de Conciliação e Arbitragem da Câmara de Comércio Internacional, como em vigor na data de inicio do procedimento;

(e) quanto ao mérito, decidirão os árbitros com base nas leis substantivas brasileiras;

(f) o laudo arbitral será definitivo e obrigará as Partes, podendo ser executado perante qualquer juízo ou tribunal competente. (...)" 
A primeira crítica que pode ser feita a esse dispositivo é que o administrador optou por inserir as duas cláusulas no contrato de concessão: a cláusula de eleição de foro e a cláusula arbitral, as quais são, a princípio, opostas, conforme já explicitado. Além disso, a cláusula de eleição de foro (29.2) está situada anteriormente à cláusula arbitral (29.4), o que aparentemente demonstra uma preferência pela via estatal de solução de controvérsias. Contudo, há uma delimitação no escopo da cláusula de eleição de foro: aplica-se às questões "que não possam ser solucionadas de forma amigável ou por meio da arbitragem". Ou seja, se a cláusula de eleição de foro é a exceção e a de arbitragem é regra, seria mais adequado que a de foro fosse posterior à de arbitragem.

A par da questão de localização no contrato — que é de menor importância -, impõe-se a análise da expressão "que não possam ser solucionadas de forma amigável ou por meio da arbitragem". Como a lei aplicável ao contrato é a lei brasileira (29.1) ${ }^{48}$ entende-se que a cláusula de foro está restrita às questões que não puderem ser resolvidas por arbitragem nos termos da Lei de Arbitragem brasileira (Lei $n^{\circ}$ 9.307/96).

A Lei de Arbitragem prevê a intervenção do Poder Judiciário nas seguintes hipóteses: ${ }^{49}$

(i) art. $7^{\circ}$ - mecanismo de execução específica da cláusula compromissória. Previsão de citação da parte recalcitrante para celebração do compromisso em juízo e, caso não compareça à audiência, o juiz decidirá sobre o conteúdo deste e sua sentença valerá como o próprio compromisso. Tal procedimento ocorrerá perante o órgão do Poder Judiciário a que, originariamente, tocaria o julgamento da causa;

(ii) art. $9^{\circ}$ - celebração de compromisso judicial. A celebração se dará perante o juízo ou tribunal onde tiver curso a demanda;

(iii) art. 11, parágrafo único - caso as partes não tenham fixado os honorários dos árbitros no compromisso, o árbitro requererá ao órgão do poder Judiciário que seria competente para julgar, originariamente, a causa que os fixe por sentença;

(iv) art. 13, § $2^{\circ}$ - quando as partes tiverem nomeado árbitros em número par, e os árbitros não chegarem a um acordo quanto à nomeação de mais um árbitro, as partes requererão ao órgão do Poder Judiciário a que tocaria, originariamente, o julgamento da causa a nomeação do árbitro;

(v) art. 16, $\S 2^{\circ}$ - quando houver a necessidade de nomeação de árbitro substituto e a convenção arbitral nada dispuser, se as partes não conseguirem chegar a um acordo, a parte interessada procederá conforme o mecanismo previsto no art. $7^{\circ}$ (item i acima), salvo se as partes tivessem declarado não aceitar substituto;

48 Cláusula 29.1: "Este contrato será executado, regido e interpretado de acordo com as leis brasileiras, que serão rigorosamente cumpridas pelo Concessionário no exercício dos seus direitos e na execução de suas obrigações aqui previstas".

49 Sobre intervenção do Poder Judiciário na arbitragem, v. Jacob Dolinger e Carmen Tiburcio, Arbitragem comercial internacional, Parte II, XIII, Renovar, 2003, p. 349 e ss. 
(vi) art. $20, \S 1^{\circ}-$ no caso de incompetência do árbitro ou do tribunal. bem como de nulidade, invalidade ou ineficácia da convenção de arbitragem, serão as partes remetidas ao órgão do Poder Judiciário competente para julgar a causa; ${ }^{50}$

(vii) art. $22, \S 2^{\circ}$ - no caso de ausência de testemunha convocada pelo árbitro ou tribunal para prestar depoimento, poderá o árbitro ou o presidente do tribunal requerer à autoridade judiciária que conduza a testemunha renitente;

(viii) art. 22, $\S 4^{\circ}$ - havendo necessidade de medidas coercitivas ou cautelares, os árbitros poderão solicitá-las ao órgão do Poder Judiciário que seria, originariamente, competente para julgar a causa;

(ix) art. 25 - sobrevindo no curso da arbitragem controvérsia acerca de direitos indisponíveis e verificando-se que de sua existência, ou não, dependerá o julgamento, o árbitro ou o tribunal remeterá as partes à autoridade competente do Poder Judiciário, suspendendo o procedimento arbitral;

(x) art. 33 - nas hipóteses previstas no art. 32, a parte interessada poderá pleitear ao órgão do Poder Judiciário competente a decretação da nulidade da sentença arbitral;

(xi) art. 36 - para a execução da sentença arbitral estrangeira aplica-se o disposto no art. 484 do CPC - aplicação das mesmas regras para execução da sentença nacional.

Assim, a cláusula de eleição de foro do contrato de concessão se aplica a todas essas hipóteses que o legislador brasileiro retirou a competência do árbitro e a atribuiu ao Poder Judiciário. Portanto, a princípio, nesses casos, a autoridade judiciária competente não será a indicada pela Lei ${ }^{\circ} 9.307 / 96$, mas aquela escolhida expressamente pelas partes na cláusula de eleição de foro. ${ }^{51}$ Conforme mencionado acima, há alguns riscos nessa escolha prévia, como por exemplo no caso das medidas cautelares (item viii acima), em que o bem ou a pessoa a ser atingido pela medida pode não estar sob a jurisdição direta do foro escolhido.

Todavia, o principal risco decorrente da redação da cláusula de eleição de foro do contrato de concessão (restrita às matérias que não possam ser solucionadas de forma amigável ou por arbitragem) está no item ix acima - aplicação do art. 25 da Lei de Arbitragem. Segundo este artigo, o árbitro é incompetente para decidir questões relacionadas a direitos indisponíveis, devendo nesse caso tal questão ser remetida ao Poder Judiciário e o julgamento suspenso até que a decisão seja proferida. Ora, como existe grande controvérsia na doutrina quanto à natureza do contrato de concessão para exploração e produção de petróleo e gás - havendo uma corrente forte que advoga a sua natureza de contrato administrativo ${ }^{52}-$, sem muita dificul-

$50 \mathrm{O} \S 2^{\circ}$ do mesmo artigo prevê que se não for acolhida a exceção de incompetência, suspeição ou impedimento do árbitro ou dos árbitros, terá normal prosseguimento a arbitragem, sem prejuízo de vir a ser examinada a decisão pelo órgão do Poder Judiciário competente, quando da eventual propositura da demanda de que trata o art. 33 da Lei (ação de nulidade da sentença arbitral).

51 Salvo quanto à ação de nulidade do laudo que deverá necessariamerite ser proposta no foro da sede da arbitragem.

52 Essa corrente é capitaneada por Maria Sylvia Zanella Di Pietro, que defende que o contrato de exploração e produção de petróleo e gás é um contrato de concessão atípico, chamado contrato 
dade poder-se-ia defender que diversas questões do contrato de concessão não poderiam ser submetidas à arbitragem. Isso porque um contrato administrativo envolve direitos indisponíveis, que por natureza não são passíveis de solução por arbitragem. Abre-se, portanto, uma enorme brecha para se buscar a ineficácia da cláusula arbitral.

Além disso, haveria a hipótese - ainda que remota - de se entender que a expressão " que não possam ser solucionadas de forma amigável ou por arbitragem" é muito vaga e, portanto, representa uma falta de acordo inequívoco das partes sobre qual meio de solução de controvérsias deveria prevalecer no contrato, acabando por se invalidar a cláusula arbitral - que é a exceção à jurisdição comum.

Note-se que o escopo da cláusula de eleição de foro não está apenas restrito às questões que não puderem se resolvidas por arbitragem, mas também àquelas que não puderem ser solucionadas de forma amigável. Isso porque a cláusula 29.3 refere-se à conciliação, em consonância com o art. 43, X, da Lei $n^{\circ}$ 9.478/97, conforme visto acima. Ocorre que a cláusula 29.3 não prevê uma conciliação ou mediação - que implicam necessariamente na intervenção de um terceiro -, mas tão-somente um mecanismo de negociação entre as próprias partes. Ou seja, a cláusula prevê apenas que as partes envidarão todos os esforços para resolver entre si a controvérsia. Definitivamente não se trata de conciliação.

Além disso, na mesma cláusula 29.3 ("conciliação") regula-se a hipótese de as partes firmarem acordo para recorrer a um perito internacional. A possibilidade da perícia é, sem dúvida, desejável, pois muitas vezes a controvérsia pode envolver questões eminentemente técnicas que seriam melhor resolvidas com a ajuda de um perito, especialista na matéria. Todavia, a localização da regra dentro da cláusula de conciliação é inapropriada. Prevê, ainda, a cláusula, que caso seja feita a opção pelo perito, o recurso à arbitragem só poderá ocorrer após este ter emitido seu parecer fundamentado. Ou seja, a decisão do perito não é definitiva e, caso uma das partes não fique satisfeita, poderá recorrer à arbitragem. Além disso, parece-nos que a referência a perito internacional não significa que o perito deva ser de outra nacionalidade, mas que seja um especialista na indústria do petróleo, com experiência internacional. Aqui, mais uma vez, questiona-se o alcance da expressão "internacional' utilizada pelo legislador.

Quanto à cláusula compromissória (29.4), pode-se tecer os seguintes comentários:

(i) no caput da cláusula, a utilização do verbo "poderá" ("então essa parte poderá submeter essa disputa ou controvérsia à arbitragem") ao invés de "deverá" contribui para retirar a efetividade da cláusula. A jurisprudência arbitral tem reconhecido essa espécie de cláusula - que representa mera faculdade e não uma

de concessão de uso de bens públicos, de acordo com os arts. 20 e 176 da Constituição federal. No extremo oposto, Toshio Mukai, que defende a natureza de contrato privado, eis que a ANP atua no âmbito de uma atividade econômica. Para um amplo relato sobre essa controvérsia na doutrina, $v$. Marilda Rosado de Sá Ribeiro, Direito do petróleo: as joint ventures na indústria do petróleo, 2* ed., Renovar, 2003, p. 339 e ss. 
obrigação - como patológica, que muitas vezes impossibilita a instauração da arbitragem; ${ }^{53}$

(ii) a alínea "a" fez uma opção rígida por três árbitros (tribunal arbitral) e talvez o valor da disputa não justifique os altos custos de uma arbitragem formada por três árbitros. Em algumas situações, um único árbitro poderia ser suficiente;

(iii) a sede da arbitragem será no Rio de Janeiro - arbitragem nacional. Ou seja, o administrador não utilizou a faculdade do art. $43, \mathrm{X}$, de se prever uma arbitragem internacional - fora do território nacional;

(iv) a faculdade prevista na alínea " $c$ " — de poderem ser apresentados documentos em outro idioma, a critério dos árbitros - é desejável, pois freqüentemente os documentos da indústria do petróleo estão em inglês ou as testemunhas são estrangeiras, mais familiarizadas com a língua inglesa. Reduz-se, portanto, os altos custos de tradução:;

(v) a alínea "d" prevê que a arbitragem se realizará de acordo com as Regras de Conciliação e Arbitragem da $\mathrm{CCI}$, em vigor na data de início do procedimento. Acredita-se que a intenção foi estabelecer uma arbitragem institucional, administrada pela Corte de Arbitragem da Câmara de Comércio Internacional (CCI), embora só se tenha referido às regras dessa Câmara, o que também pode dar margem a dúvidas, pois se pode especular se o legislador pretendeu determinar uma arbitragem ad hoc, segundo as referidas normas. Há, ainda, uma imprecisão na terminologia utilizada para essas regras, pois a denominação correta é Regulamento de Arbitragem da Câmara de Comércio Internacional. ${ }^{55}$ Além disso, a referência a regras de conciliação nesta alínea é inapropriada, pois esta rege apenas a arbitragem (e nem mesmo existe um único regulamento de conciliação e arbitragem da $\mathrm{CCI}^{56}$ ). Por fim, a referência

53 No Agravo de Instrumento $n^{\circ} 70003666258$, julgado pela $2^{2}$ Câmara Cível do Tribunal de Justiça do Estado do Rio Grande do Sul em 13.11.2002, invalidou-se a cláusula compromissória que utilizava o verbo "poderia", por se entender que não houve acordo inequívoco a favor da arbitragem. Sobre a decisão, v. Jacob Dolinger e Carmen Tiburcio, Arbitragem comercial interna. cional, Parte II, I, Renovar, 2003, p. 170. Sobre cláusulas patológicas, vide Selma M. Ferreira Lemes, Cláusulas arbitrais ambiguas ou contraditórias e a interpretação da vontade das partes. In: Reflexōes sobre arbitragem (in memoriam de Cláudio Vianna de Lima), LTr, 2002, p. 188 e ss. 54 Note-se, contudo, que a cláusula refere-se à desnecessidade de tradução oficial. A tradução literal levaria à conclusão de que ainda seria necessária a apresentação de tradução livre. Todavia, acreditamos que essa decisão ficará a critério dos próprios árbitros, que poderão dispensar qualquer tradução de documentos em inglês ou outra língua com a qual sejam familiarizados. Essa decisão pouparia as partes de terem que arcar com os altos custos de tradução (ainda que livre) e estaria consentânea com a informalidade que deve reger o procedimento arbitral.

s5 Regulamento disponível no site da Corte de Arbitragem da CCI: hup://www.iccwbo.org/court/english/arbitration/pdf documents/rules/rules arb brazilian.pdf. Acesso em 28.09.2005.

S6 O Regulamento de Conciliação da $\mathrm{CCl}$ de 1988 foi substituído pelo Regulamento ADR de 1.07.2001. Para a CCI, a sigla ADR significa Amicable Dispute Resolution, ou seja, métodos amigáveis de solução de disputas, como por exemplo, a mediação. Confira-se a introdução constante no site da CCI sobre esse regulamento: "The ICC ADR Rules offer a framework for the amicable settlement of commercial disputes with the assistance of a neutral. They were launched in 2001 to 
à aplicação das regras em vigor na data de início do procedimento arbitral é desejável, pois presume-se que a alteração é benéfica e, portanto, devem ser privilegiadas as novas regras.$^{57}$ Contudo, há que se observar, dada a natureza processual das referidas regras, que essa é a solução que seria aplicável mesmo que no silêncio da cláusula, pois não regem o mérito da controvérsia, para o que se aplicaria a máxima tempus regit actum.

(vi) a alínea "e" reitera disposição já prevista na cláusula 29.1 de que a lei aplicável ao contrato, e conseqüentemente a lei que regerá o mérito da arbitragem, será a lei brasileira (leis substantivas);

(vii) finalmente, a alínea " $\mathrm{f}$ " enuncia uma das principais características da arbitragem: o laudo arbitral é definitivo e obrigará as partes. Ou seja, não há possibilidade de recurso da decisão arbitral. Prevê, ainda, que o laudo arbitral poderá ser executado perante qualquer juízo ou tribunal competente. Assim, com relação à execução não se aplica a eleição do foro feita na cláusula 29.2, o que é desejável, pois não se sabe de antemão em que lugar o laudo terá que ser executado provavelmente onde a parte perdedora tiver bens ou onde tiver que ser executada uma obrigação de fazer - sendo arriscado aplicar a eleição de foro para a execução. Note-se, ainda, que o contrato preferiu adotar a terminologia "laudo arbitral", ao invés da nova denominação dada pela Lei de Arbitragem: sentença arbitral.

\title{
b) Primeira Rodada
}

Confira-se abaixo a redação da cláusula de eleição de foro, conciliação e arbitragem do contrato de concessão da primeira rodada de licitação da ANP realizada em 1999:

\author{
"Cláusula Vigésima-Nona - Regime Jurídico \\ (...) \\ Foro
}

replace the 1988 Rules of Conciliation. Under the ICC ADR Rules, parties may freely choose the settlement technique they consider most appropriate to their situation. This may be mediation, whereby a neutral helps the parties to settle their differences through negotiation; a mini-trial, in which a panel comprising a neutral and a manager from each party proposes a solution or gives an opinion; or a neutral evaluation of a point of law or fact. Common to all these techniques is the fact that the decision reached by or in collaboration with the neutral is not binding upon the parties, unless they agree otherwise. The success of the chosen technique will depend largely on the qualities of the neutral. He or she may be designated directly by the parties or appointed by ICC. In the latter case, the parties may specify certain requirements as to the qualifications or attributes the neutral should possess. Lastly, the parties are not limited to a single technique, but may find it useful to apply a combination of settlement techniques." (http://www.iccwbo.org/index adr.asn. Acesso em 28.09.2005).

57 O Regulamento de Arbitragem da CCI em vigor é de 1998, tendo sido apenas alterado apenas o art. 4 (tabelas de encargos administrativos e de honorários de árbitros) do anexo III (cuśas e honorários da arbitragem) do Regulamento em 01.07.2003. 
29.2 Fica eleito o foro da Cidade do Rio de Janeiro para resolver quaisquer dúvidas, controvérsias, conflitos ou pendências surgidos entre as partes em decorrência da execução ou da interpretação deste Contrato, que não possam ser solucionados de forma amigável ou por meio de arbitragem.

\section{Conciliação}

29.3 As Partes envidarão todos os esforços no sentido de resolver entre si, amigavelmente, toda e qualquer disputa ou controvérsia decorrente deste Contrato ou com ele relacionada. Poderão também, desde que firmem acordo unânime por escrito, recorrer a perito internacional, para dele obter um parecer fundamentado que possa levar à superação da disputa ou controvérsia.

29.3.1 Firmado um acordo para a intervenção de perito internacional, nos termos do parágrafo 29.3, o recurso à arbitragem, previsto no parágrafo 29.4, somente poderá ser exercido depois que esse perito tiver emitido seu parecer fundamentado.

\section{Arbitragem}

29.4 Observado o disposto no parágrafo 29.3.1, se a qualquer momento uma parte considerar que inexistem condições para uma solução amigável de uma disputa ou controvérsia a que se refere o parágrafo 29.3, então essa parte poderá submeter essa disputa ou controvérsia à arbitragem, dando inicio ao processo respectivo, de acordo com os seguintes principios:

(a) a arbitragem será realizada de acordo com as Regras de Conciliação e Arbitragem da Câmara de Comércio Internacional, ou quaisquer outras normas acordadas por todas as Partes envolvidas.

(b) serão três os árbitros, escolhidos um por cada Parte (com todos os Concessionários agindo como uma única só Parte) e o terceiro, que exercerá as funções de presidente, nomeado de acordo com as Regras da CCI;

(c) o lugar da arbitragem será a cidade do Rio de Janeiro, Estado do Rio de Janeiro, Brasil;

(d) o idioma a ser utilizado no processo de arbitragem será a língua portuguesa, sendo que as partes poderão submeter depoimentos ou documentos em inglês (ou qualquer outra idioma se os árbitros assim decidirem), sem necessidade de tradução oficial;

(e) quanto ao mérito, decidirão os árbitros com base nas leis substantivas brasileiras;

(f) o laudo arbitral será definitivo e obrigará as Partes, podendo ser executado perante qualquer juízo ou tribunal competente. (...)" 58

58 O contrato de concessão da primeira rodada está disponível em: http://www.anp.gov.br/brasilrounds/round1/HTML/Edital_pt.htm. Acesso em 28.09.2005. 
Observe-se que as cláusulas de eleição de foro (29.2), conciliação (29.3) e o caput da cláusula de arbitragem (29.4) possuem redação idênticas às cláusulas da rodada zero. Note-se que permaneceu a utilização do verbo "poderá”, ao invés de "deverá" no caput da cláusula arbitral.

A diferença está apenas nas alíneas da cláusula de arbitragem, conforme comentários abaixo:

(i) a alínea referente à aplicação das regras da CCI passou a ser a primeira, alínea "a", e não mais a alínea "d", como ocorria na cláusula da rodada zero. A alteração parece positiva, pois essa é uma disposição de extrema relevância e, além disso, evita que na alínea " $a$ " seja feita referência às regras previstas na alínea " $d$ ", tal como ocorria na cláusula da rodada anterior. Todavia, limita-se a alínea "a" a fazer referência apenas às regras da Câmara de Comércio Internacional (e novamente com a denominação incorreta das regras), e não à administração do procedimento arbitral pela corte de arbitragem daquela Câmara. Por fim, adicionou-se uma referência à possível aplicação de "quaisquer outras normas acordadas por todas as partes envolvidas". Ou seja, as regras da CCI podem não vir a ser aplicadas, caso haja acordo das partes para a aplicação de outras. A expressão acrescentada põe em dúvida se a intenção foi criar de fato uma arbitragem institucional. De qualquer forma, podem vir a ser aplicadas regras de outra instituição ou até mesmo pode vir a ser instituída uma arbitragem ad hoc, com aplicação das regras da UNCITRAL, por exemplo, desde que haja acordo nesse sentido;

(ii) A alínea " $b$ " prevê que a arbitragem será conduzida por três árbitros, na mesma linha da cláusula da rodada anterior. Contudo, foi acrescentada previsão de que todos os concessionários agirão como uma única parte. Ou seja, os concessionários em conjunto nomearão um árbitro e a ANP, do outro lado, nomeará o outro árbitro. $\mathrm{O}$ terceiro (presidente) será nomeado de acordo com as regras da $\mathrm{CCI}$ (não há qualquer referência à aplicação de outras regras, tal como previsto na alínea " $a$ "). A previsão acrescentada suscita a questão da arbitragem multipartes, na qual mais de uma parte integra cada pólo (ou em apenas um deles). Tal possibilidade pode vir a ocorrer no âmbito desses contratos de concessão, em razão da freqüente celebração de joint ventures entre os concessionários. O regulamento de arbitragem da $\mathrm{CCI}$ possui uma regra específica para esse tipo de arbitragem, in verbis:

\section{"Art. 10. Múltiplas Partes}

1) Quando houver múltiplas partes, como Requerentes ou como Requeridas, e quando a controvérsia for submetida a três árbitros, os múltiplos Requerentes, conjuntamente, ou os múltiplos Requeridos, da mesma forma, deverão designar um árbitro, nos termos do art. 9.

2) Na ausência de nomeação conjunta e de um método para a constituição do Tribunal Arbitral, a Corte nomeará todos os seus membros e designará um deles para atuar como presidente. Neste caso, a Corte terá liberdade para escolher qualquer pessoa que julgue competente para atuar como árbitro, aplicando o artigo 9, quando julgar conveniente." 59 
Assim, a regra da CCI estabelece que as partes situadas em cada pólo (requerentes ou requeridas) deverão nomear conjuntamente um único árbitro. A disposição é semelhante ao que tentou prever a disposição da alínea "b". Todavia, embora pouco provável, pode surgir a hipótese de os concessionários não estarem todos do mesmo lado, ou seja, pode ser que algum concessionário esteja no pólo oposto, ao lado da ANP, por exemplo. Nesse caso, a nosso ver, a referida disposição deve ser interpretada à luz do artigo 10 do Regulamento da $\mathrm{CCI}$ : as partes com interesses coincidentes integram um único pólo e cada pólo nomeia um árbitro. Caso não haja acordo, os três árbitros serão nomeados pela corte de arbitragem da $\mathrm{CCl}$;

(iii) as alíneas " $c$ ", " $d "$, " $e$ ", e "f" permanecem com a mesma redação da cláusula da rodada zero, com a única exceção que a alínea " $d$ " faz expressa menção ao inglês, ao prever que as partes poderão submeter depoimentos ou documentos em inglês (ou outro idioma - a critério dos árbitros) sem necessidade de tradução oficial. A cláusula anterior não se referia expressamente ao inglês e a apresentação de documentos/ depoimentos em outro idioma dependia da autorização dos árbitros. Agora, a rigor, somente a apresentação em outro idioma - diverso do português e do inglês - precisará da autorização dos árbitros.

\section{c) Segunda Rodada}

A redação das cláusulas de eleição de foro, conciliação e arbitragem da segunda rodada de licitação, realizada em 2000 , era a seguinte:

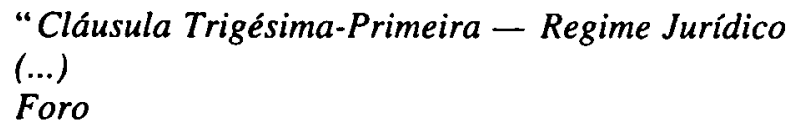

31.2 Fica eleito o foro da Cidade do Rio de Janeiro para resolver quaisquer dúvidas, controvérsias, conflitos ou litigios surgidos entre as Partes em decorrência da execução ou da interpretação deste Contrato.

\section{Conciliação}

31.3 As Partes envidarão todos os esforços no sentido de resolver entre si, amigavelmente, toda e qualquer disputa ou controvérsia decorrente deste Contrato ou com ele relacionada. Poderão também, desde que firmem acordo unânime por escrito, recorrer a perito internacional, para dele obter um parecer fundamentado que possa levar à superação da disputa ou controvérsia.

31.3.1 Firmado um acordo para a intervenção de perito internacional, nos termos do parágrafo 31.3 , o recurso à arbitragem, previsto no parágrafo 31.4, somente poderá ser exercido depois que esse perito tiver emitido seu parecer fundamentado.

Dutco Constr. Co. (French Cass civ. 7 Jan. 1992). Vide comentários ao caso em Jacob Dolinger e Carmen Tiburcio, Arbitragem comercial internacional, Parte II, V, Renovar, 2003. 
Arbitragem

31.4 Se a qualquer momento uma parte considerar que inexistem condições para uma solução amigável de uma disputa ou controvérsia a que se refere o parágrafo 31.3, então essa parte poderá submeter essa disputa ou controvérsia à arbitragem, dando início ao processo respectivo, de acordo com os seguintes princípios:

(a) A arbitragem será realizada de acordo com as Regras da Câmara de Comércio Internacional, ou quaisquer outras normas acordadas por todas as Partes envolvidas.

(b) Serão três os árbitros, escolhidos um por cada Parte (com todos os Concessionários agindo como uma única só Parte) e o terceiro, que exercerá as funções de presidente, nomeado de acordo com as Regras da Câmara de Comércio Internacional, ou outras normas escolhidas conforme o parágrafo 31.4(a);

(c) O lugar da arbitragem será a cidade do Rio de Janeiro, Estado do Rio de Janeiro, Brasil;

(d) $O$ idioma a ser utilizado no processo de arbitragem será a língua portuguesa, sendo que as Partes poderão submeter depoimentos ou documentos em inglês (ou qualquer outro idioma se os árbitros assim decidirem), sem necessidade de tradução oficial;

(e) Quanto ao mérito, decidirão os árbitros com base nas leis substantivas brasileiras;

(f) $O$ laudo arbitral será definitivo e obrigará as Partes, podendo ser executado perante qualquer juizo ou tribunal competente. (...)" 60

A segunda rodada representou, sem dúvida, um retrocesso com relação às rodadas anteriores, no que se refere às cláusulas de eleição de foro e de arbitragem. A crítica feita às cláusulas das rodadas anteriores quanto à coexistência dessas duas cláusulas num mesmo contrato se aplica com mais razão na segunda rodada. Isso porque a cláusula de eleição de foro deixou de ser a exceção e passou a ser a regra (continuando a estar situada anteriormente à cláusula arbitral), pois foi retirada a expressão "que não possam ser solucionadas de forma amigável ou por meio de arbitragem". Assim, a cláusula de eleição de foro genérica retirou praticamente toda a eficácia da cláusula arbitral, uma vez que ausente qualquer delimitação do escopo de cada uma delas. Se a situação já não era favorável para a arbitragem, ficou ainda pior. A manutenção do verbo "poderá" no caput da cláusula arbitral em nada contribui para melhorar esse cenário.

60 O contrato de concessão da segunda rodada está disponivel em: http://www.anp.gov.br/brasilrounds/round2/Pdocs/Pinicial/Pframe01.htm. Acesso em 28.09.2005. 
Não houve qualquer alteração na redação das cláusulas de conciliação (31.3) e no caput da cláusula de arbitragem (31.4). ${ }^{61}$ Apenas foram alteradas na cláusula arbitral as alíneas " $a$ " - correta retirada da menção à conciliação - e "b" repetição da denominação das regras e menção a outras regras que porventura venham a ser acordadas pelas partes, corrigindo-se a omissão constante da rodada anterior.

\section{d) Terceira Rodada}

Confira-se a redação das cláusulas de eleição de foro, conciliação e arbitragem do contrato de concessão da terceira rodada, realizada em 2001:

"Cláusula Trigésima-Primeira - Regime Jurídico

(...)

Foro

31.2 Fica eleito o foro da Cidade do Rio de Janeiro, Estado do Rio de Janeiro, Brasil, para resolver quaisquer dúvidas, controvérsias, conflitos ou litígios surgidos entre as Partes em decorrência da execução ou da interpretação deste Contrato, que não venham a ser resolvidos por conciliação ou arbitragem.

\section{Conciliação}

31.3 As Partes envidarão todos os esforços no sentido de resolver entre si, amigavelmente, toda e qualquer disputa ou controvérsia decorrente deste Contrato ou com ele relacionada. Poderão também, desde que firmem acordo unânime por escrito, recorrer a perito internacional, para dele obter um parecer fundamentado que possa levar ao encerramento da disputa ou controvérsia.

31.3.1 Firmado um acordo para a intervenção de perito internacional, nos termos do parágrafo 31.3 , o recurso à arbitragem, previsto no parágrafo 31.4, somente poderá ser exercido depois que esse perito tiver emitido seu parecer fundamentado.

\section{Arbitragem}

31.4 Se a qualquer momento uma parte considerar que inexistem condições para uma solução amigável de uma disputa ou controvérsia a que se refere o parágrafo 31.3, então essa parte poderá submeter essa disputa ou con-

61 Há uma pequena alteração no caput da cláusula arbitral sem qualquer importância prática: retirou-se a ressalva constante das cláusulas anteriores de que o recurso à arbitragem deveria observar o disposto na cláusula referente à intervenção do perito internacional ("observado o disposto no parágrafo 29.3.1"). A situação permanece a mesma, pois a cláusula 31.3.1 continua a prever que firmado o acordo para a intervenção de perito internacional, o recurso à arbitragem somente poderá ser exercido depois que esse perito tiver emitido seu parecer fundamentado. 
trovérsia à arbitragem, dando início ao processo respectivo, de acordo com os seguintes princípios:

(a) A arbitragem será realizada de acordo com as Regras da Câmara de Comércio Internacional, ou quaisquer outras normas acordadas por todas as Partes envolvidas.

(b) Serão três os árbitros, escolhidos um por cada Parte (com todos os Concessionários agindo como uma única só Parte) e o terceiro, que exercerá as funções de presidente, nomeado de acordo com as Regras da Câmara de Comércio Internacional, ou outras normas escolhidas conforme o parágrafo 31.4(a);

(c) O lugar da arbitragem será a cidade do Rio de Janeiro, Estado do Rio de Janeiro, Brasil;

(d) O idioma a ser utilizado no processo de arbitragem será a língua portuguesa, sendo que as Partes poderão submeter depoimentos ou documentos em inglês (ou qualquer outro idioma se os árbitros assim decidirem), sem necessidade de rradução oficial;

(e) Quanto ao mérito, decidirão os árbitros com base nas leis substantivas brasileiras;

(f) O laudo arbitral será definitivo e obrigará as Partes, podendo ser executado perante qualquer juizo ou tribunal competente. (...)" 62

Quanto à cláusula de eleição de foro, o enorme retrocesso causado pela redação ampla da referida cláusula no contrato da segunda rodada foi parcialmente corrigido, voltando-se praticamente à redação das rodadas zero e primeira. Assim, foi novamente inserida a frase (ligeiramente diferente, mas com o mesmo efeito prático): "que não venham a ser resolvidos por conciliação ou arbitragem". A arbitragem voltou, portanto, a ser a regra, e a eleição de foro a exceção. A única inovação aparentemente favorável foi a menção à conciliação, e não mais a "forma amigável". A inovação foi aparente, pois a cláusula de conciliação (31.3) continuou prevendo um método amigável de simples negociação entre as partes, e não propriamente uma conciliação.

As cláusulas de conciliação (31.3) e arbitragem (31.4) continuaram com a mesma redação da rodada anterior. Ressalte-se que foi mantida a utilização do verbo "poderá" com relação ao recurso à arbitragem.

62 O contrato de concessão da terceira rodada está disponível em: http://www.anp.gov.br/brasilrounds/round3/index.html. Acesso em 28.09.2005. 
Como a redação das cláusulas de eleição de foro, conciliação e arbitragem nos contratos de concessão da quarta (realizada em 2002) e quinta (realizada em 2003) rodadas é idêntica, analisaremos essas duas rodadas em conjunto. Confira-se a diç̧ão das referidas cláusulas:

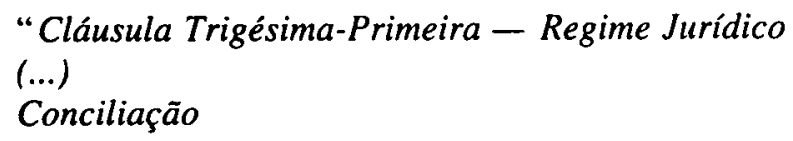

31.2 As Partes envidarão todos os esforços no sentido de resolver entre si, amigavelmente, toda e qualquer disputa ou controvérsia decorrente deste Contrato ou com ele relacionada. Poderão também, desde que firmem acordo unânime por escrito, recorrer a perito internacional, para dele obter um parecer fundamentado que possa levar ao encerramento da disputa ou controvérsia.

31.2.1 Firmado um acordo para a intervenção de perito internacional, nos termos do parágrafo 31.2 , o recurso à arbitragem, previsto no parágrafo 31.3, somente poderá ser exercido depois que esse perito tiver emitido seu parecer fundamentado.

\section{Arbitragem}

31.3 Se a qualquer momento uma parte considerar que inexistem condiçōes para uma solução amigável de uma disputa ou controvérsia a que se refere o parágrafo 31.2, então essa parte deverá submeter essa disputa ou controvérsia à arbitragem, dando inicio ao processo respectivo, de acordo com o Regulamento de Arbitragem da Câmara de Comércio Internacional e em consonância com os seguintes princípios:

(a) Serão três os árbitros, escolhidos um por cada Parte (com todos os Concessionários agindo como uma única só Parte) e o terceiro, que exercerá as funções de presidente;

(b) A sede da arbitragem e o lugar da prolatação da sentença arbitral será a cidade do Rio de Janeiro, Estado do Rio de Janeiro, Brasil;

(c) O idioma a ser utilizado no processo de arbitragem será a língua portuguesa, sendo que as Partes poderão submeter depoimentos ou documentos em inglês (ou qualquer outro idioma se os árbitros assim decidirem), sem necessidade de tradução oficial;

(d) Quanto ao mérito, decidirão os árbitros com base nas leis substantivas brasileiras;

(e) O laudo arbitral será definitivo e obrigará as Partes; 
31.4 Para os efeitos da Lei $n^{\circ}$ 9.307/96, para as questões que não versem sobre direitos patrimoniais disponiveis, e onde mais se aplicar, as Partes elegem o foro da Cidade do Rio de Janeiro, Brasil, com único competente, com renúncia expressa a qualquer outro, por mais privilegiado que seja. $(\ldots), 63$

Verifica-se que a redação das cláusulas de eleição de foro, conciliação e arbitragem dos contratos da quarta e quinta rodada tiveram alterações substanciais com relação às rodadas anteriores, conforme se verá a seguir.

A primeira grande modificação foi com relação à posição da cláusula de eleição de foro (31.4), que passou a vir posteriormente à cláusula compromissória (31.3), o que é mais consentâneo com o fato de ser a arbitragem a regra para efeitos do contrato. Todavia, a modificação aparentemente benéfica pode ter causado um efeito ainda pior para a eficácia da cláusula arbitral. Isso porque a cláusula de eleição de foro passou a estar restrita às "questões que não versem sobre direitos patrimoniais disponiveis". Ora, o temor mencionado quando da interpretação da cláusula da rodada zero fica ainda maior, pois, como visto, existe uma corrente da doutrina que defende a natureza jurídica de contrato administrativo para os contratos de concessão para exploração e produção de petróleo e gás. Ora, contrato administrativo envolve direitos indisponíveis, que conseqüentemente não são arbitráveis, nos termos do art. $1^{\circ}$ da Lei $n^{\circ} 9.307 / 96 .{ }^{64}$ Dessa forma, com essa expressa referência feita pela cláusula de eleição de foro, aumenta-se a brecha para se fugir da arbitragem, com a simples defesa de que determinada controvérsia se refere a direitos indisponíveis. Como se não bastasse, a referida cláusula adicionou ainda a expressão " $e$ onde mais se aplicar", contribuindo para praticamente sepultar a cláusula arbitral, caso esse seja o desejo de uma das partes.

A cláusula arbitral (31.3) possui as seguintes modificações:

(i) não obstante o comentário feito acima sobre a alteração na redação da cláusula de eleição de foro, houve uma importante modificação no caput da cláusula arbitral: passou-se a utilizar o verbo "deverá" ("então essa parte deverá submeter essa disputa ou controvérsia à arbitragem..."), ao invés de "poderá" (utilizado nas rodadas anteriores), contribuindo para tentar garantir maior efetividade à arbitragem;

(ii) passou-se a prever a aplicação do regulamento da CCI no caput da cláusula, e não mais em uma de suas alíneas. Além disso, a denominação das referidas regras foi corretamente alterada para "Regulamento de Arbitragem da Câmara de Comércio Internacional". Deixou-se, ainda, de prever a possibilidade de aplicação de outras

63 O contrato de concessão da quarta rodada está disponível em: http://www.anp.gov.br/brasilrounds/round4/index.html. Acesso em 28.09.2005; e o contrato de concessão da quinta rodada está disponível em: http://www.brasil-rounds.gov.br/round5/round5/edital.asp. Acesso em 28.09.2005. 64 Lei $\mathrm{n}^{\circ}$ 9.307/96: "Art. $1^{\circ}$. As pessoas capazes de contratar poderão valer-se da arbitragem para dirimir litígios relativos a direitos patrimoniais disponíveis." 
regras que venham. a ser acordadas posteriormente pelas partes, o que não possui grande relevância, pois as partes podem sempre, de comum acordo, alterar o que foi estipulado na cláusula arbitral. A alteração, contudo, contribui para trazer maior segurança ao investidor, em razão da aplicação das regras da $\mathrm{CCI}$ - instituição renomada e conhecida internacionalmente. Todavia, mantém-se a mera referência ao Regulamento da $\mathrm{CCI}$ e não a uma arbitragem administrada por essa Câmara;

(iii) retirou-se na alínea "a" a forma de nomeação do presidente do tribunal que constava das cláusulas anteriores. Essa alteração não possui qualquer relevância, pois se aplicará a regra pertinente do Regulamento da $\mathrm{CCI}$;

(iv) a alínea "b" passou a mencionar expressamente a palavra "sede" (além da referência ao lugar da prolatação da sentença arbitral), ao invés de "lugar da arbitragem". A alteração na denominação — apesar de mais apropriada — não possui qualquer efeito prático, pois a sede ou o lugar da arbitragem continua a ser a cidade do Rio de Janeiro;

(v) as alíneas " $c$ " (idioma) e " $d$ " (lei aplicável ao mérito) não sofreram qualquer modificação;

(vi) na alínea " $e$ " foi retirada a frase "podendo ser executada perante qualquer juízo ou tribunal competente".

\section{f) Sexta Rodada}

No que se refere à sexta rodada, realizada em 2004, o contrato de concessão contém algumas alterações face às rodadas quarta e quinta, in verbis:

\section{Cláusula Trigésima-Primeira - Regime Jurídico \\ (...) \\ Conciliação}

31.2 As Partes envidarão todos os esforços no sentido de resolver entre si, amigavelmente, toda e qualquer disputa ou controvérsia decorrente deste Contrato ou com ele relacionada. Poderão também, desde que firmem acordo unânime por escrito, recorrer a perito internacional, para dele obter um parecer fundamentado que possa levar ao encerramento da disputa ou controvérsia.

31.2.1 Firmado um acordo para a intervenção de perito internacional, nos termos do parágrafo 31.2 , o recurso à arbitragem, previsto no parágrafo 31.3, somente poderá ser exercido depois que esse perito tiver emitido seu parecer fundamentado.

(...)

Arbitragem "ad hoc"

31.4 Se a qualquer momento uma parte considerar que inexistem condições para uma solução amigável de disputa ou controvérsia a que se refere o 
parágrafo 31.2, deverá submeter essa disputa ou controvérsia a processo arbitral "ad hoc", utilizando como parâmetro as regras estabelecidas no Regulamento da Corte de Arbitragem da Câmara de Comércio Internacional e em consonância com os seguintes preceitos:

(a) A escolha dos árbitros seguirá o rito estabelecido no Regulamento da Corte de Arbitragem da Câmara de Comércio Internacional;

(b) Serão três os árbitros. Cada Parte escolherá um árbitro. Os dois árbitros assim escolhidos designarão o terceiro árbitro, que funcionará como presidente;

(c) A cidade do Rio de Janeiro, Brasil, será a sede da arbitragem e o lugar da prolação da sentença arbitral;

(d) O idioma a ser utilizado no processo de arbitragem será a língua portuguesa. As Partes poderão, todavia, instruir o processo com depoimentos ou documentos em qualquer outro idioma se os árbitros assim decidirem, sem necessidade de tradução oficial;

(e) Quanto ao mérito, decidirão os árbitros com base nas leis substantivas brasileiras;

(f) A sentença arbitral será definitiva e seu conteúdo obrigará as Partes;

Foro

31.5 Para os efeitos da Lei no 9.307/96, para as questōes que não versem sobre direitos patrimoniais disponiveis, as Partes elegem o foro da Cidade do Rio de Janeiro, Brasil, como único competente, com renúncia expressa a qualquer outro, por mais privilegiado que seja." 65

Verifica-se que a cláusula de conciliação da sexta rodada não teve alterações de conteúdo com relação às rodadas anteriores. Portanto, remete-se o leitor às observações já feitas anteriormente. Da mesma forma, a cláusula de eleição de foro reproduz o texto adotado nas rodadas quarta e quinta.

Assim, ainda se percebe a coexistência das cláusulas de eleição de foro e compromissória, sem que fique bem delineado o âmbito de aplicação de cada uma, persistindo a crítica já feita a respeito sobre o risco de se escolher um foro para as diversas possibilidades de intervenção do Judiciário na arbitragem, inclusive para a concessão de medidas cautelares.

65 O contrato de concessão da sexta rodada está disponível em: http://www.brasilrounds.gov.br/round6/contrato/Contrato_R6.pdf). Acesso em 28.09.2005. 
Acredita-se que a melhor solução para tais contratos seja realmente a exclusão total da cláusula de eleição de foro. Todavia, no caso de se pretender manter a cláusula, o recurso à jurisdição estatal escolhida só poderá ocorrer: (i) se as partes (de comum acordo) desistirem da arbitragem; ou (ii) se a questão objeto da disputa disser respeito a direito patrimonial indisponível ou estiver compreendida nos limites do poder discricionário da ANP. A manutenção das duas cláusulas com a redação atual pode dar margem a dúvidas no momento do surgimento da controvérsia para se determinar qual a autoridade competente para solucioná-la: a arbitral ou a judicial?

Ademais, observa-se alteração substancial quanto à cláusula de arbitragem, já que claramente a ANP optou por arbitragem 'ad hoc', " utilizando como parâmetro as regras estabelecidas no Regulamento da Corte de Arbitragem da Câmara de Comércio Internacional". Além disso, prevê o contrato que "A escolha dos árbitros seguirá o rito estabelecido no Regulamento da Corte de Arbitragem da Câmara de Comércio Internacional".

Não se sabe a razão pela qual a ANP decidiu adotar a arbitragem 'ad hoc' em detrimento da institucional, já que essa última garante mais segurança às Partes e aos árbitros. A arbitragem 'ad hoc' exige uma escolha muito mais criteriosa dos árbitros, que devem ser profissionais com bastante experiência na área da arbitragem, pois não haverá uma secretaria para lhes dar apoio e tirar dúvidas sobre o procedimento arbitral. A arbitragem 'ad hoc' ainda apresenta problema adicional relativamente à escolha dos árbitros. Como esses são escolhidos pelas Partes, no caso em que uma delas se recuse a participar da arbitragem e indicar o seu árbitro haverá necessidade de recurso ao procedimento judicial previsto no art. $7^{\circ}$ da Lei de Arbitragem, ${ }^{66}$ o que poderá atrasar a instauração da arbitragem e suscitar controvérsias suplementares.

66 Art. $7^{\circ}$ Existindo cláusula compromissória e havendo resistência quanto à instituição da arbitragem, poderá a parte interessada requerer a citação da outra parte para comparecer em juízo a fím de lavrar-se o compromisso, designando o juiz audiência especial para tal fím.

$\S 1^{\circ} \mathrm{O}$ autor indicará, com precisão, o objeto da arbitragem, instruindo o pedido com o documento que contiver a cláusula compromissória.

$\$ 2^{\circ}$ Comparecendo as partes à audiência, o juiz tentará, previamente, a conciliaçâo acerca do litígio. Não obtendo sucesso, tentará o juiz conduzir as partes à celebração, de comum acordo, do compromisso arbitral.

$\$ 3^{\circ}$ Não concordando as partes sobre os termos do compromisso, decidirá o juiz, após ouvir o réu, sobre seu conteúdo, na própria audiência ou no prazo de dez dias, respeitadas as disposiçōes da cláusula compromissória e atendendo ao disposto nos arts. 10 e $21, \S 2^{\circ}$, desta Lei.

$\$ 4^{\circ}$ Se a cláusula compromissória nada dispuser sobre a nomeação de árbitros, caberá ao juiz, ouvidas as partes, estatuir a respeito, podendo nomear árbitro único para a soluçāo do litígio.

$\$ 5^{\circ}$ A ausência do autor, sem justo motivo, à audiência designada para a lavratura do compromisso arbitral importará a extinçāo do processo sem julgamento de mérito.

$\$ 6^{\circ}$ Não comparecendo o réu à audiência, caberá ao juiz, ouvido o autor, estatuir a respeito do conteúdo do compromisso, nomeando árbitro único.

$\$ 7^{\circ}$ A sentença que julgar procedente o pedido valerá como compromisso arbitral." 
Ademais, no que diz respeito ao procedimento, a alteracao nao parece ser substancial, pois as regras da $\mathrm{CCl}$ serão o parâmetro a ser adotado pelos árbitros. Assim, perde-se a principal vantagem das arbitragens institucionais que é poder contar com o apoio administrativo da instituição arbitral sem que isso represente qualquer alteração substancial quanto às regras aplicáveis ao procedimento. Caso a ANP realmente deseje manter a escolha pela arbitragem 'ad hoc', parece que a melhor alternativa seria optar pela escolha das regras da UNCITRAL, especialmente criadas para condução de arbitragens 'ad hoc'. Alem disso, sugere-se a indicação da CCI como autoridade nomeadora do árbitro caso uma das Partes falhe na nomeação do árbitro. A CCI possui regras especialmente para essa finalidade (Rules of ICC as Appointing Authority in UNCITRAL or Ohter Ad Hoc Arbitration Proceedings), em vigor desde janeiro de 2004. Assim, as dificuldades surgidas com a recalcitrância de uma das partes nomear árbitro serão minimizadas, já que a CCI nomeará o árbitro dessa Parte, bem como o terceiro árbitro se for o caso.

\section{f) Sétima rodada ${ }^{67}$}

A ser realizada em outubro de 2005. Há algumas alterações face às rodadas anteriores:

Cláusula Trigésima-Primeira - Regime Jurídico

Lei Aplicável

31.1.1 Este Contrato será executado, regido e interpretado de acordo com as leis brasileiras, que serão rigorosamente cumpridas pelo Concessionário no exercício dos seus direitos e na execução de suas obrigações.

\section{Conciliação}

31.1.2 As Partes envidarão todos os esforços no sentido de resolver entre si, amigavelmente, toda e qualquer disputa ou controvérsia decorrente deste Contrato ou com ele relacionada. Poderão também, desde que firmem acordo unânime por escrito, recorrer a perito internacional, para dele obter um parecer fundamentado que possa levar ao encerramento da disputa ou controvérsia.

31.1.3 Firmado um acordo para a intervenção de perito internacional, nos termos do parágrafo 31.1.2, o recurso à arbitragem, previsto no parágrafo 31.1.5. somente poderá ser exercido depois que esse perito tiver emitido seu parecer fundamentado.

(...)

67 A minuta do contrato de concessão da sétima rodada está disponível em: http://www.anp.gov.br/brasil-rounds/edital/Contrato_R7_A.pdf. Acesso em 28.09.2005. 
Arbitragem "ad hoc"

31.1.5 Se a qualquer momento uma parte considerar que inexistem condições para uma solução amigável de disputa ou controvérsia a que se refere o parágrafo 31.1.2, deverá submeter essa disputa ou controvérsia a processo arbitral "ad hoc", utilizando como parâmetro as regras estabelecidas no Regulamento da Corte de Arbitragem da Câmara de Comércio Internacional e em consonância com os seguintes preceitos:

(a) A escolha dos árbitros seguirá o rito estabelecido no Regulamento da Corte de Arbitragem da Câmara de Comércio Internacional;

(b) Serão três os árbitros. Cada Parte escolherá um árbitro. Os dois árbitros assim escolhidos designarão o terceiro árbitro, que funcionará como presidente;

(c) A cidade do Rio de Janeiro, Brasil será a sede da arbitragem e o lugar da prolação da sentença arbitral;

(d) O idioma a ser utilizado no processo de arbitragem será a língua portuguesa. As Partes poderão, todavia, instruir o processo com depoimentos ou documentos em qualquer idioma se os árbitros assim decidirem, sem a necessidade de tradução oficial.

(e) Quanto ao mérito, decidirão os árbitros com base nas leis substantivas brasileiras

(f) A sentença arbitral será definitiva e seu conteúdo obrigará as Partes.

(g) Havendo necessidade de medidas cautelares, preparatórias ou incidentais, ou outras medidas acautelatórias, a Parte interessada poderá requerê-las diretamente ao Poder Judiciário, com fundamento na legislação brasileira aplicável.

Foro

31.1.6 Para os efeitos da Lei no 9.307/96, para as questões que não versem sobre direitos patrimoniais disponiveis, as Partes elegem o foro da Cidade do Rio de Janeiro, Brasil, como único competente, com renúncia expressa a qualquer outro, por mais privilegiado que seja.

(...)

Verifica-se que as cláusulas de conciliação, arbitragem e eleição de foro da sétima rodada não tiveram alterações de conteúdo com relação à sexta rodada. Portanto, remete-se o leitor às observações feitas anteriormente. 
Todavia, é de se destacar a referência expressa à possibilidade de as Partes ajuizarem cautelares antes ou durante o procedimento arbitral, requerendo-as diretamente ao Judiciário. Cabem aqui algumas observações. Primeiramente, há de se louvar essa preocupação, principalmente face à cláusula de eleição de foro, bastante abrangente. Nada obstante, ainda há adaptações a serem feitas na redação dessa cláusula. Como a cláusula de eleição de foro é bastante genérica e estabelece como competente o foro do Rio de Janeiro “(...) como único competente, com renúncia expressa a qualquer outro, por mais privilegiado que seja" seria recomendável que fosse inserida a observação de que o ajuizamento das cautelares pode ser feito em qualquer foro, dependendo da localização do bem ou pessoa objeto da medida, e não somente na cidade do Rio de Janeiro. Além disso, dois pontos merecem destaque. O primeiro é que a redação da clausula é facultativa, ou seja, as partes "podem" recorrer ao Judiciário. Caso as partes prefiram, elas podem se utilizar, por exemplo, do mecanismo previsto pela CCI segundo o qual uma autoridade é nomeada exclusivamente para decidir sobre a medida cautelar (ICC Rules for a Pre-Arbitral Referee Procedure.$^{68}$ Observa-se, também, que a cláusula permite o ajuizamento de cautelar diretamente pelas Partes perante o Judiciário, mesmo na hipótese de já estar instaurado o procedimento arbitral, ampliando o disposto no art. $22 \S 4^{\circ}$ da Lei de Arbitragem, ${ }^{69}$ que só menciona os árbitros.

\section{$V-$ Conclusão}

A arbitragem, a despeito de existir no Brasil desde a Constituição Imperial de 1824, tem desenvolvimento recente entre nós. Isso se deve a vários fatores: 1) a legislação em vigor era anacrônica e ultrapassada; 2) o Judiciário adotava uma postura altamente desfavorável ao seu desenvolvimento no país; e 3) as partes desconheciam as vantagens da sua utilização e temiam pela reação do Judiciário, o que gerava insegurança na adoção desta forma de solução de controvérsias.

Atualmente este cenário mudou. Destacamos: 1) a promulgação da Lei $n^{\circ}$ 9.307/96, que trouxe decisivas inovações na matéria, e, com elas, a expectativa de que a arbitragem possa se tornar uma alternativa eficaz à atuação do Poder Judiciário, já sobrecarregado em demasia; 2) a postura favorável do Judiciário brasileiro, que tem adotado posições claramente pró-arbitragem; e 3) o início da implantação de

68 "In force since 1990, the Rules established for this procedure allow parties to apply to a "referee" for urgent provisional measures in relation to a dispute. The parties themselves may select the referee, who, failing that, is appointed by the Chairman of the International Court of Arbitration. Measures the referee orders are binding until decided otherwise by a court or Arbitral Tribunal. Application of the ICC Pre-Arbitral Referee Procedure requires written agreement between the parties, concluded either as part of the relevant contract or later." Informação obtida no site da CCI. (http://www.iccwbo.org/court/english/pre_arbitral/all_topics.asp). Acesso em 06.10.2005.

69 Art. $22 \S 4^{\circ}$. Ressalvado o disposto no $\S 2^{\circ}$, havendo necessidade de medidas coercitivas ou cautelares, os árbitros poderão solicitá-las ao órgão do Poder Judiciário que seria, originariamente, competente para julgar a causa. 
uma cultura favorável à utilização da via arbitral para a solução de litígios de maior complexidade.

Assim, diante deste cenário favorável ao instituto, espera-se que no Brasil, a arbitragem venha a se tornar a forma mais utilizada de solução de litígios na indústria do petróleo e gás, tal como ocorre no exterior.

Até o momento, contudo, não se tem notícia de que qualquer litígio no âmbito dos contratos de concessão de E\&P celebrados nas rodadas de licitação da ANP tenha sido submetido à via arbitral. No caso envolvendo a Petrobras, Petroserv S.A. e a Queiroz Galvão Perfurações S.A. (as duas últimas tornaram-se cessionárias do contrato posteriormente a sua celebração na rodada zero), de um lado, e a ANP, do outro, sobre controvérsia decorrente do pedido de prorrogação do prazo da fase de exploração do contrato de concessão do Bloco BCAM-40, a questão foi levada ao Judiciário pelas concessionárias e não se tem registro de qualquer exceção de incompetência argüida em favor da cláusula compromissória. ${ }^{70}$

Acredita-se que no caso as partes recorreram ao Judiciário porque não está claro se todas as controvérsias decorrentes ou relacionadas ao contrato devem necessariamente ser submetidas à arbitragem, tendo em vista a coexistência das cláusulas de eleição de foro e arbitral e a ausência de determinação das matérias que são passíveis de solução por arbitragem. Além disso, como o caso envolvia a necessidade de medida cautelar, parece que as partes preferiram continuar na via judicial também para a discussão do mérito.

70 Sobre o caso, v. Jacob Dolinger e Carmen Tiburcio, Arbitragem comercial internacional, Parte II, XV, Renovar, 2003, p. 162 e ss. 


\section{Direitos Reais e Autonomia da Vontade}

\begin{tabular}{|c|c|}
\hline 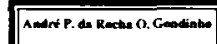 & André P. da Rocha O. Gondinho \\
\hline $\begin{array}{l}\text { Direitos Reaise } \\
\text { Autonomia da Vontode }\end{array}$ & $\begin{array}{l}\text { Ref. } 0298 \\
\text { Brochura } \\
167 \text { págs. } \\
\text { Form. } 13,5 \times 21 \\
2001 \\
\text { ISRN } 85-7147-231-0\end{array}$ \\
\hline
\end{tabular}

0 autor enfrenta temas pouco explorados por nossa doutrina: o princípio da tipicidade dos direitos reais e toda a problemática resultante da limitação legal dos direitos reais no Brasil. Sua proposta tem por objetivo apurar a rigidez do princípio da tipicidade dos direitos reais, fixando, para tal empreitada, os contornos dogmáticos do princípio e a possibilidade da autonomia da vontade moldar situaçōes reais, ou com eficácia real, merecedoras de tutela jurídica.

\section{Divórcio e Separação Judicial \\ Doutrina - Legislação - Jurisprudência - Direito Comparado}

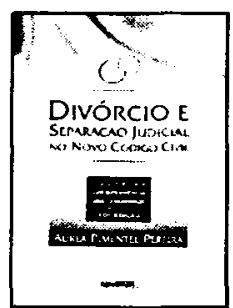

É de grande utilidade para os profissionais e interessados em Direito de Família. A autora, em linguagem clara, comenta, artigo por artigo, a Lei do Divórcio, apontando suas alteraçōes decorrentes da Constituição de 1988. Os aspectos controvertidos são abordados, com especial cuidado, unindo a longa experiência da autora, que muitas vezes diverge de outros comentadores, mas justifica seu entendimento e cita doutrina e jurisprudência.

\section{Do Pátrio Poder à Autoridade Parental Repensando Fundamentos Juridicos da Relação entre Pais e Filhos}

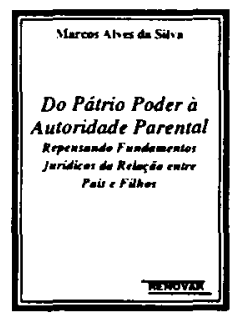

Marcos Alves da Silva

Ref. 0395

Brochura

244 págs.

Form. 13,5×21

2002

ISBN 85-7147-848-1

Compreende a migração operada do CC à Constituição, captando, à luz da teoria crítica do Direito Civil, o sistema clássico originário do CC brasileiro e o Direito Constitucional da Família. Para tratar do percurso que inicia com o pátrio poder e que alcança a autoridade parental, compreendendo o Código de 1916 e a nova denominação ("poder familiar") do CC de 2002, apreendeu 0 autor um campo de saber que rompe as fronteiras tradicionais do público e do privado.

\section{Elementos de Responsabilidade Civil}

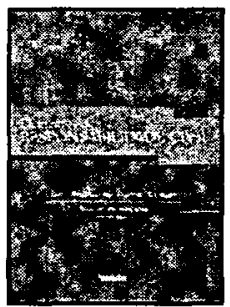
Luiz Roldão de Freitas Gomes

Ref. 0252

Encadernado

446 págs.

Form. $16 \times 23$

2000

ISBN 85-7147-165-7

De caráter altamente didático, discorre sobre o conceito da responsabilidade civil, em cotejo com a penal, sobre sua classificaçāo, controvertida, em contratual e extracontratual, e analisa a responsabilidade fundada na culpa e no risco. Perpassa pelos fundamentos de uma e outra, procurando demonstrar que ambas hão de conviver, respondendo a diversas exigências. 